\title{
'Yeşil Alan'dan Geleneğe: Somut/Somut Olmayan Kültürel Miras Dikotomisi, Kültürel Peyzaj ve Yedikule Bostancılığını Dünya Mirası Olarak Korumak
}

\author{
From 'Green Space' to Tradition: Tangible/Intangible Cultural \\ Heritage Dichotomy, Cultural Landscape and Protecting \\ Yedikule Vegetable Gardening as World Heritage
}

\author{
(1) Bahar Aykan, (1) İpek Başyurt \\ Marmara Üniversitesi Fen Edebiyat Fakültesi, Sosyoloji Bölümü, İstanbul
}

\section{ÖZ}

Yedikule bostanları İstanbul'un Bizans döneminden günümüze uzanan köklü bostancılık geleneğinin yaşayan nadir örneklerinden biridir ve UNESCO Dünya Mirası Listesi'ndeki Tarihi Yarımada'nın sınırları içinde yer alır. Tarihi kara surlarını çevreleyen bu bostanlar, 2013 yılından bu yana park ve rekreasyon alanına dönüştürülmesine yönelik projelerle gündeme gelmektedir. Bu durum ilk bakışta bostanların Dünya Mirası statüsü ile çelişiyormuş gibi görülse de bostan alanları kara surlarının çevresindeki 'yeşil alan'lar olarak kabul edilir ve olduğu gibi koruma statüsünde değildir. Bu makale, Yedikule bostancılarıyla gerçekleştirilen derinlemesine mülakatlara dayanarak, bu geleneğin sürdürülebilmesi için kara surlarıyla bir bütün olarak, kültürel peyzaj yaklaşımıyla ele alınıp korunmasına yönelik sözleşme nezdinde atılabilecek adımları tartışmayı amaçlamaktadır. 1992 yılında oluşturulan kültürel peyzaj kategorisi bir alanı Dünya Mirası yapan somut ve somut olmayan özelliklerin birlikte tanımlanıp korunabilmesini mümkün kılmaktadır. Bu kategori, kuşaktan kuşağa aktarılan geleneksel yöntem ve tekniklerle sürdürülen Yedikule bostancılığının, yüzyıllardır bir arada varolduğu kara surlarıyla birlikte gelişimini sürdüren organik peyzaj olarak yeniden listelenip koruma altına alınmasına olanak sağlamaktadır. Böyle bir değişiklik bostancılığın sürdürülmesi konusunda ulusal ve uluslararası kamuoyu oluşmasına ve bostancıların bu mirasın taşıyıcıları olarak desteklenerek karar alma süreçlerine dahil edilmesi yönünde politikalar ve projeler geliştirilmesine imkân sağlayacaktır.

Anahtar sözcükler: Dünya Mirası; kültürel miras; kültürel peyzaj; UNESCO; Yedikule bostanları.

\section{ABSTRACT}

As rare living examples of Istanbul's long-standing vegetable gardening tradition dating from the Byzantine period, Yedikule vegetable gardens are located within the borders of the Historic Areas of İstanbul in the UNESCO World Heritage List. Surrounding the historic land walls, these vegetable gardens are on the agenda since 2013 with plans to transform them into parks and recreation areas. Although this may appear contradictory to the World Heritage status of the vegetable gardens at first glance, these gardens are considered to be 'green spaces' surrounding the land walls and do not have a protection status. Based on in-depth interviews with Yedikule vegetable gardeners, this article aims to discuss the steps that can be taken in the presence of the convention to address and protect the vegetable gardening tradition together with the land walls through a cultural landscape approach. The category of cultural landscapes that was created in 1992 has enabled the identification and protection of both tangible and intangible characteristics of an area as a World Heritage site. Yedikule vegetable gardening has been carried on with traditional methods and techniques for generations, and cultural landscape category offers an opportunity for its protection as an organically evolved continuing landscape, together with the land walls with which it has co-existed for centuries. Such a change will provide the possibility to generate national and international public opinion to sustain vegetable gardening tradition and to develop policies and projects to support gardeners as heritage bearers and involve them in the decision-making processes.

Keywords: World Heritage; cultural heritage; cultural landscape; UNESCO; Yedikule vegetable gardens.

Geliş tarihi: 02.10.2018 Kabul tarihi: 24.09.2019

Online yayımlanma tarihi: 10.10.2019

İletişim: Bahar Aykan.

e-posta: aykanbahar@gmail.com 


\section{Giriş}

İstanbul'un yüzyıllar boyunca sebze ve yeşillik ihtiyacını karşılayan bostanları günümüzde yok denecek kadar azalmış durumdadır. Geçmişi Bizans dönemine dayanan bostancılık faaliyeti, Osmanlı döneminde de gelişerek devam etmiş ve uzman bahçıvan olarak kabul edilen bostancılar zanaat loncaları şeklinde örgütlenmiştir (Kaldjian, 2004, s. 285). Yirminci yüzyılın sonunda Avrupa yakasında Çekmece'den Rumeli Feneri'ne, Anadolu yakasında da Tuzla'dan Anadolu Feneri'ne kadarki alanda yaklaşık 1200 adet sebze meyve bahçesi olduğu belirtilirken (Günçıkan, 1990), günümüzde oldukça sınırlı sayıdaki bostan arazisi hızla büyüyen, betonlaşan ve kentsel dönüşüm politikalarının etkisiyle soylulaştırılan İstanbul'un çeperine kaymış durumdadır.'

Kentin içinde gittikçe küçülerek de olsa halen varlığını sürdürebilen nadir bostan alanlarından biri tarihi Yedikule bostanlarıdır (Şekil I-3). 2010 yılında İstanbul Büyükşehir Belediyesi (IBB) tarafından yayımlanan İstanbul'un 100 Bahçesi adlı bir kitaba göre Bizans kralı II. Theodosius tarafından 5. yüzyılda tamamlanan tarihi kara surlarının 1985 yılında Dünya Mirası Listesi'ne dahil edilerek korunma altına alınmış olması, onu çevreleyen bostanların da günümüze erişebilmesinde etkili olmuştur: "İstanbul'da bulunan, adı bilinen ancak kendilerinden eser kalmamış diğer bostanların aksine Yedikule bostanları surdibinde olduğu için yapılaşmadan kurtulabilmiştir" (Akdaş, 2010, s. 67). Ancak Dünya Mirası sınırları içinde yer alması tarihi bostanların olduğu gibi korunmasını garanti altına almamaktadır. Çünkü aslında Dünya Mirası olarak koruma altına alınan Yedikule bostancılık geleneği ya da bostanları değil, tarihi kara surlarıdır. ${ }^{2}$

Kara surlarını çevreleyen bostancılık faaliyeti de en az surlar kadar eski, ${ }^{3}$ onlarla bütünleşmiş ve bir arada varolagelmiş bir gelenektir. ${ }^{4}$ Ancak sadece kara surları boyunca uzanan alandaki bostanlar, onlar da surların tampon bölgesini oluşturdukları için, Dünya Mirası olarak kabul edilen bölgenin sınırları içinde yer alır (Şekil 4 ve 5). Bir unsurun Dünya Mirası Listesi'ne kabul edilebilmesi için belirlenmiş on istisnai evrensel değer kriterinden en az birini karşılaması gerekir. ${ }^{5}$ Adaylık dosyasına göre İstanbul Tarihi Yarımadası'nın istisnai evrensel değerini Bizans ve Osmanlı dönemlerine ait arkeolojik kalıntılar ve camii, saray, kilise gibi tarihi mimari yapılar oluşturur (UNESCO,

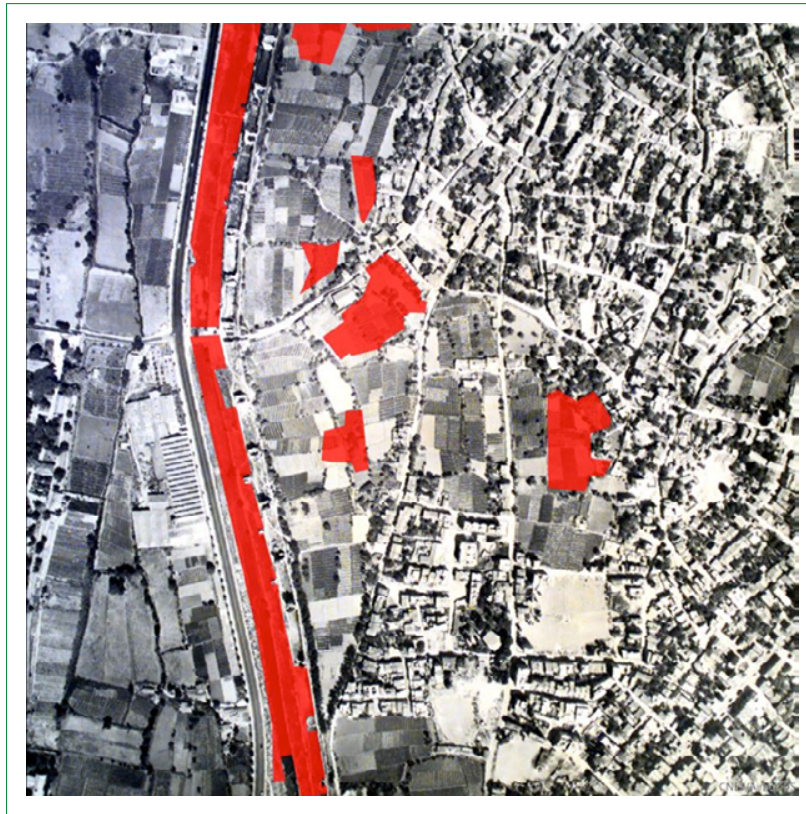

Şekil I. Yedikule bostanlarının 1966 yılına ait bir görünümü; görselde kırmızı renk ile belirtilen bölgeler günümüzde hala varlığını sürdürebilen son bostan alanlarını işaret etmektedir.

(Eli Weaverdyck, https://cityandagricultureistanbul.org/ [Erişim tarihi: 02.03.2019], E. Weaverdyck'ın izni doğrultusunda kullanılmıştır.)

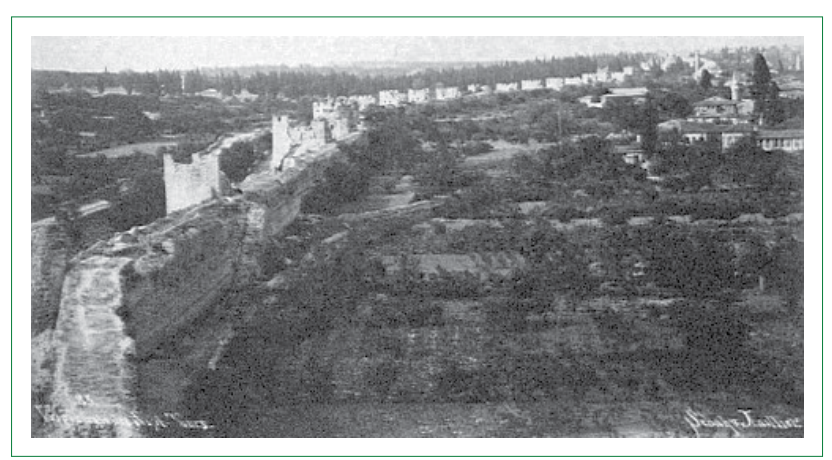

Şekil 2. Yirminci yüzyıl başı; kara surları ve Yedikule bostanlardan bir görünüm. (A. Spov ve A. Han, 15-18. Yüzylllarda Yedikule Bostanları, https://m.bianet.org/bianet/tarim/ I 48943-15-18-yuzyillarda-yedikule-bostanlari [Erişim Tarihi: 02.03.2019])

2018a). Dosyada tarihi Yedikule bostanlarına ya da korunmasına dair bir hüküm yer almaz. Dünya Mirası olarak koruma altına alınan bölge ise "kara surlarının her iki tarafındaki alan" olarak belirtilir (UNESCO, 2018a).

Yedikule Bostancılar Derneği Başkanı Özkan Ökten'e göre, İstanbul'da bostancılık faaliyeti günümüzde özellikle Silivri, Çatalca, Başakşehir, Tuzla ve Pendik ilçelerinde sürdürülmektedir ve yaklaşık 300 aile bostancılıkla geçinmektedir (Özkan Ökten, 02.03.2018).

2 İstanbul Tarihi Yarımadası, Sultanahmet Arkeolojik Parkı, Zeyrek Camii ve çevresi, Süleymaniye Camii ve çevresi ve İstanbul Kara Surları'ndan oluşmaktadır.

3 Sur kulelerinin alt katında depo olarak yer alan odalar, bostancıların aletlerini saklayabilecekleri yerler olarak yapılmışlardır (Aksoy, 20I6). Örneğin, MS. 422 tarihli Teodosyen kanunnamesinden bir ferman, çevredeki arazi sahiplerinin iç duvarda yer alan kulelerin alt katlarını tarımsal ürün ve aletleri depolamak amacıyla kullanmalarına izin verir (Ricci, 2008, 67). Aslıhan Demirtaş'a göre, bu kullanma hakkı karşılığında bostancılar da sur duvarlarının korunması ve onarımından sorumlu olmuştur (Kılınç, 2017). Altıncı yüzyıla ait Geoponika metni üzerinde Koder'in yaptığı bir araştırma, Bizans döneminde Yedikule'de kara surlarının dışında ve içinde yaklaşık iki kilometre aralıklarla bostanlar olduğunu göstermektedir (Ricci, 2008, s. 67).

4 Alessandra Ricci'ye $(2008$, s. 67) göre kara surlarının hendeği tarım için uygun nemli bir ortam sağlamaktadır. Sulama için de bostanlarda bulunan taş kuyular kullanılır ve bu durum bostancıların maliyetlerinde önemli tasarruf sağlar. Taş kuyulara dair ilk tarihi kayıt on beşinci yüzyıla aittir. Bu kuyular hakkında detaylı bilgi için, bkz. White, Shopov ve Ostovich, 2015.

Sözleşme uygulama rehberinin 49. maddesine göre istisnai evrensel değer "ulusal sınırları aşan ve tüm insanlığın bugünkü ve gelecek nesilleri için ortak öneme haiz istisnai bir kültürel ve/veya doğal önemi” ifade eder (UNESCO, 2008). İstisnai evrensel değer kriterleri için bkz., UNESCO, 2008, 77-78. 


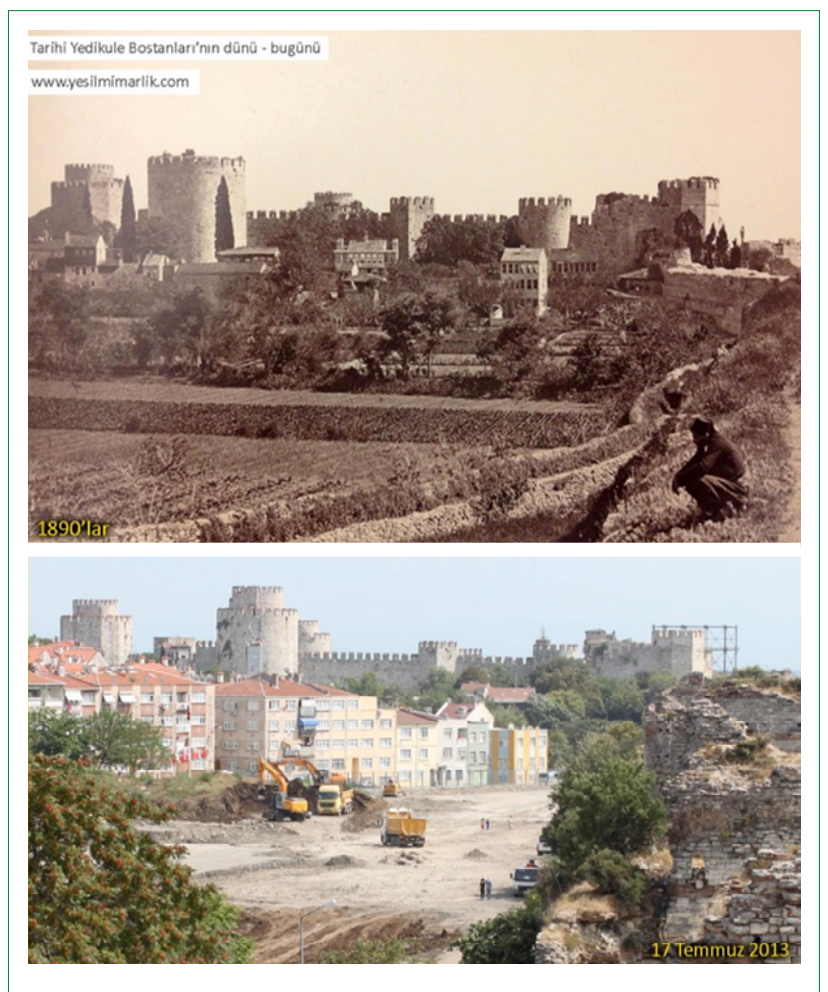

Şekil 3. Yüzyılı aşkın sürede sur içindeki bostan alanlarının dönüşümü. (Yeşil Mimarık, 2013, Yeşil Mimarlık'ın izni doğrultusunda kullanılmıştır.)

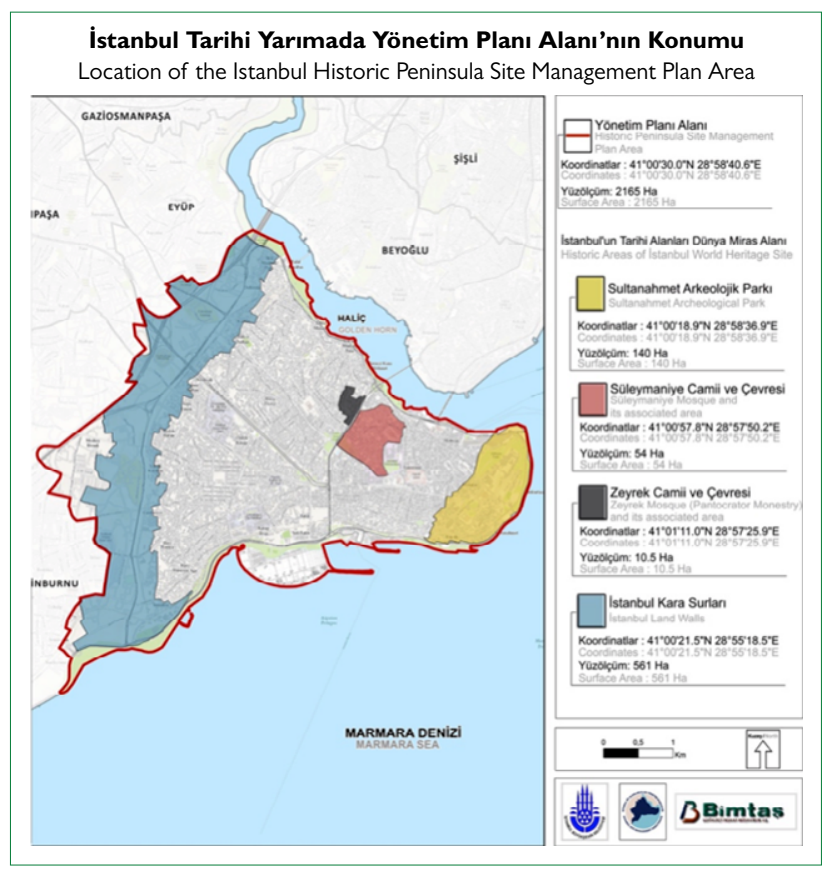

Şekil 4. İstanbul Tarihi Yarımada Yönetim Planı Alanı'nın tamamını gösterir pafta.

(İstanbul Sit Alanları Alan Yönetimi Başkanlığı'nın izni doğrultusunda kullanıımıştır.)

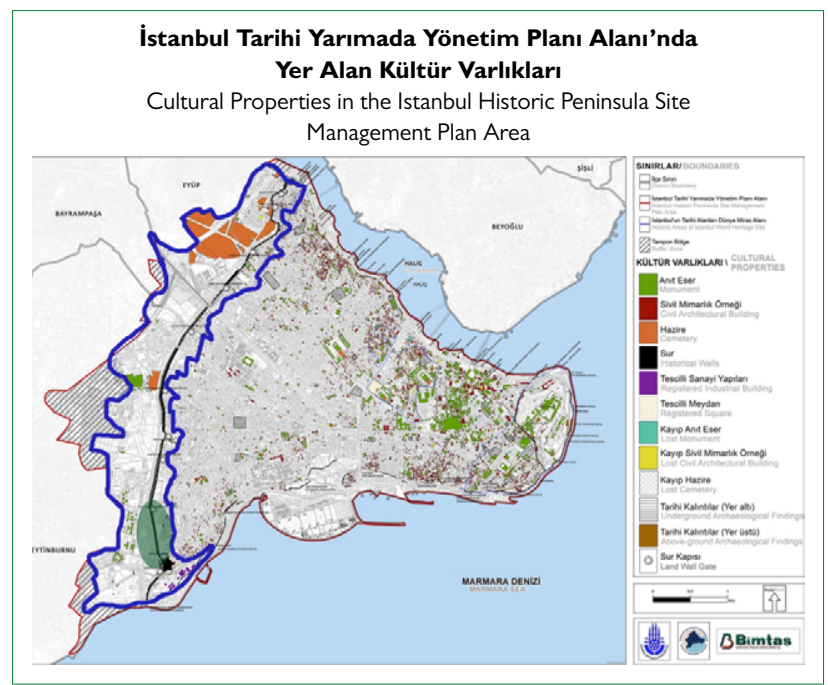

Şekil 5. Tarihi Yarımada'da yer alan anıt eser, tarihi kalıntılar gibi kültür varlıklarını gösteren pafta. Bu paftada koruma alanına Yedikule bostanlarının da dahil olduğu görülmektedir.

(İstanbul Sit Alanları Alan Yönetimi Başkanlığ’nın izni doğrultusunda kullanıımışıı.)

2005 yılına ait 1/5000 ölçekli Koruma Amaçlı Nâzım İmar Planı'nda ise bostanlar "kara surları iç koruma yeşil alanı" olarak tanımlanır (Emen ve İnce, 2013). İstanbul Sit Alanları Alan Yönetimi Başkanlığı, Dünya Mirası Komitesi'nin talepleri doğrultusunda, Tarihi Yarımada olarak tanımlanan bölgelerin sistemli bir şekilde korunabilmesi için 201 I yılında bir yönetim planı hazırlamıştır. Bu plana göre korunacak alanlar I. ve 2. Derece Koruma Bölgeleri olarak sınıflandırılır. Bostanlar "doğal niteliğini korumuş" olmalarına rağmen "Dünya Miras Alanları'nı bütünleyen alanlar" olarak 2. derece koruma bölgesi kabul edilir. ${ }^{6}$ Yönetim planı "I875 tarihli haritada yer alan günümüze kadar mevcudiyetini devam ettiren" bostan alanlarının korunacağını belirtir (İstanbul Tarihi Yarımada Yönetim Planı, 20II, s. 10I); ancak 2. Derece koruma bölgesi kabul edilen alanlarda kentsel tasarım projelerinin geliştirilebileceğini de ekler (İstanbul Tarihi Yarımada Yönetim Planı, 20II, s. 93.) (Şekil 6). Dolayısıyla Yedikule bostanları olduğu gibi koruma statüsünde değildir ve kentsel dönüşüme uğrayabilir (Şekil 7).

2006 yılında 5366 sayılı Yıpranan Tarihi ve Kültürel Taşınmaz Varlıkların Yenilenerek Korunması ve Yaşatılarak Kullanılması Hakkında Kanun kapsamına alınarak yenileme alanı ilan edilen Yedikule bostanları, son yıllarda park ve rekreasyon alanına dönüştürülmesine yönelik projelerle sıkça gündeme gelmektedir. Fatih Belediyesi tarafından 2013 yllında uygulamaya konulan "Yedikule Kapı ile Belgrad Kapı Arası Kara Surları İç Koruma Alanı Rekreasyon Projesi," adlı proje, suriçindeki 8.5 hektar alanın İstanbullu'ların "rekreasyon ve

Bu yönetim planına göre "geleneksel yol dokusu-mimari karakteri ve kültürel özellikleri günümüze kadar değişmeden korunmuş" anıt eserler, tarihi yapılar ve arkeolojik alanlar Tarihi Yarımada'nın silueti de göz önünde bulundurularak I. Derece Koruma Bölgesi olarak belirlenmiştir. Geleneksel yol dokusu, mimari karakter ve kültürel özelliklerini günümüze kadar kısmen korumuş kentsel alanlar ile doğal niteliği bozulmamış bostan alanları ise 2. Derece Koruma Bölgesi kabul edilmiştir. Bkz., İstanbul Tarihi Yarımada Yönetim Planı, 20I I, s. 93. 


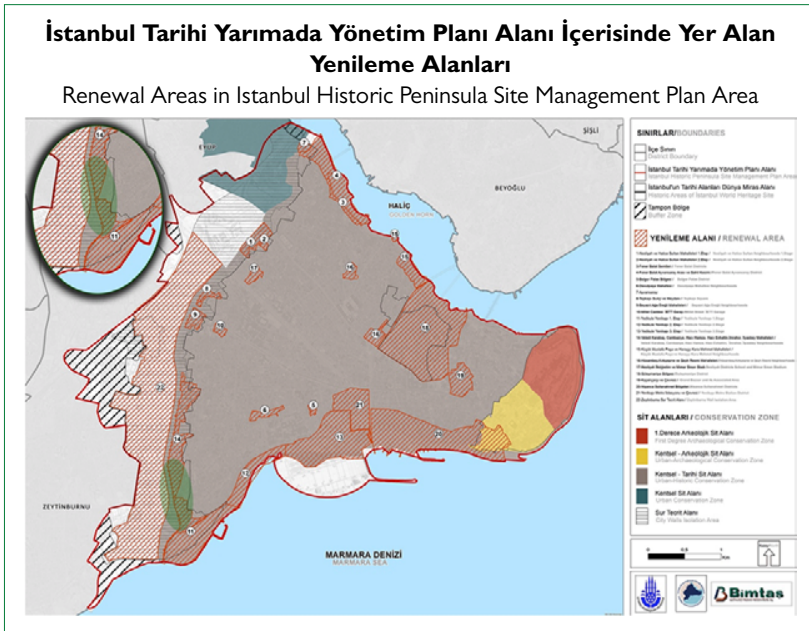

Şekil 6. Bostanların bulunduğu alanın "yenileme alanı" olarak işaretlendiğini gösterir pafta.

(İstanbul Sit Alanları Alan Yönetimi Başkanlığ’nın izni doğrultusunda kullanıımıştır.)

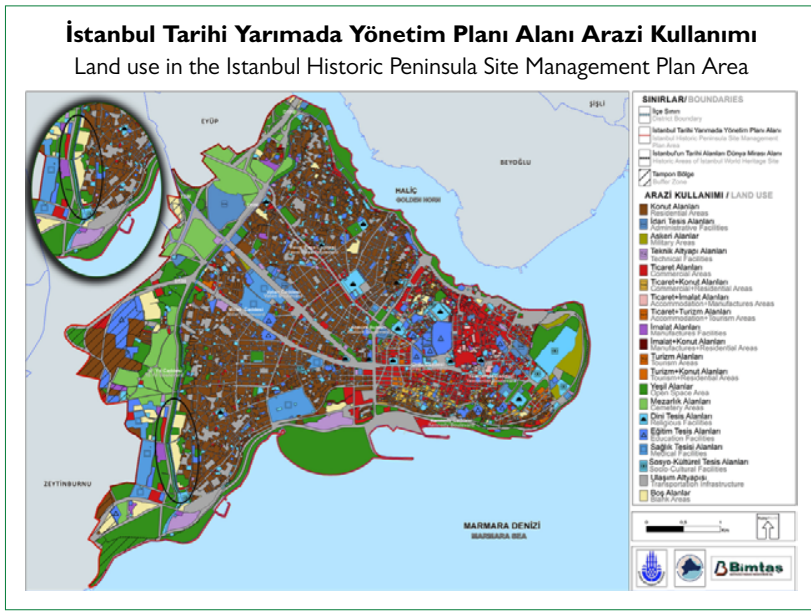

Şekil 7. Bostanların bulunduğu alanın "yenileme alanı" olarak işaretlendiğini gösterir pafta.

(İstanbul Sit Alanları Alan Yönetimi Başkanlı̆ı’nın izni doğrultusunda kullanılmışır.)

sosyal ihtiyaçlarına cevap verebilecek" bir şekilde yeniden düzenlenerek (Fatih Belediyesi, 2013, s. 255), spor alanı, otopark, yürüyüş yolu, çocuk oyun parkı, süs havuzu, restoran ve kafe gibi fonksiyonların yer aldığı bir sosyal tesise dönüştürülmesini amaçlamıştır (Şekil 8 ve 9).

\section{Suriçindeki tarihi bostanların bulunduğu bölgeyi "atıl durum-}

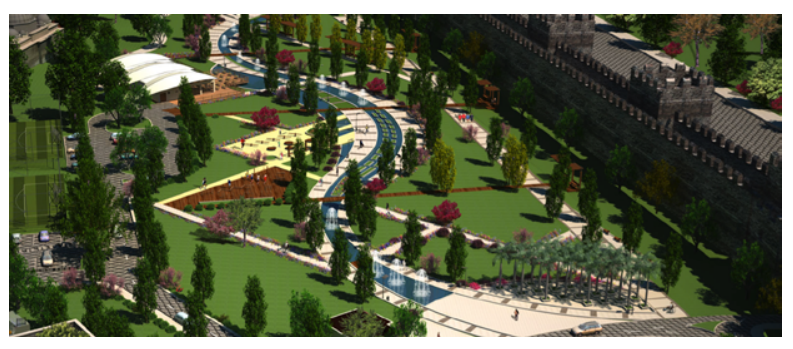

Şekil 8. Fatih Belediyesinin 2013 yılında başlattığı, ve aynı yıl iptal edilen, projeye ait bir görsel.

(Kaynak, http://kutupmimarlik.com/portfolio/kule-meydani-yedikule-kapi-ile-belgrad-kapi-arasi-kara-surlari-ic-koruma-alani-mimari-muhendislik-ve-rekreasyon-alani -uygulama-projesi/ [Erişim tarihi: 02.03.2019]

da kalmış ve hizmet olarak kullanıcıya ve kente kazandırılmamış" bir kent parçası olarak tanımlayan proje kapsamında (Fatih Belediyesi, 2013, s. 255.), aynı yılın Temmuz ayında bu alanda uzun yıllardır üretim yapan bostancılara haber verilmeksizin (hatta son mahsullerini toplamalarına da izin verilmeksizin) 27 dönüm bostana moloz dökülmüştür (Çorakbaş, Aksoy ve Ricci, 20I4, s. 16.) (Şekil I0). Proje, surları çevreleyen bostanların kültürel miras olarak koruma altına alınmasını savunan Yedikule bostancıları, sivil toplum kuruluşları, meslek örgütleri ve aktivistlerin tepkileri ve çalışmaları doğrultusunda 2014 yılında dönemin IBB Başkanı Kadir Topbaş tarafından imzalanmayarak iptal edilmiştir. ${ }^{7}$ Ancak, moloz dökülen alanın tekrar bostana dönüştürülmesi ve eski kullanıcılarına kiralanarak korunmasına yönelik talepler dikkate alınmamış ve İBB tarafından bu alanın "Kentsel Tarım Parkı" olarak yeniden düzenlenmesini öngören bir proje hazırlanmıştır.

IBB'nin Yedikule bostanlarını "kentsel tarım parkı olarak yaşatacak" bir düzenleme olarak kamuoyuna duyurduğu proje, ${ }^{8}$ suriçindeki alanın "bostan (kent bahçesi)" olarak düzenlenerek "kent içerisinde kalmış bostan alanlarının belli bölgelerde tematik olarak korunmasını ve bahçecilik tarihimizin gelecek nesillere aktarılmasını" amaçlar (IBB, 20I8). Ancak, eski projede olduğu gibi, proje alanının büyük bir kısmı yine çocuk oyun alanı, kafe, restoran, bisiklet yolu, piknik ve dinlenme alanı gibi bölümlere ayrılmıştır. "Bostan" olarak adlandırılan ama aslında "hobi bahçesi" olarak tasarlanan alan ise projenin yaklaşık üçte birini oluşturur (IBB, 20I8). Bu alanlarda kentin farklı kesimlerine bostan üretimi imkânı

Tarihi Yedikule Bostanları Koruma Girişimi (TYBKG), 2013 yılında suriçindeki bostanlara moloz döküldüğü sırada bostancılığın somut olmayan kültürel miras, bostanların da taşınmaz kültür varlıkları olarak korunmasını talep eden ve tarih, mimarlık, arkeoloji, kent planlaması, gıda aktivizmi gibi farklı ilgi alanlarına sahip bir grup kentli tarafından kurulmuştur (TYBKG, 20I7, s. II2). Suriçinde mağduriyet yaşayan bostancılarla birlikte hareket eden girişim, Yedikule Bostancılar Derneği'nin kurulmasına da destek vermiştir. "Bostancısı olmayan sebze bahçesine veya yeşil alana bostan denmez" (TYBKG, 20I7, s. I23) düşüncesinden yola çıkan bu iki paralel örgütlenme, Ziraat Mühendisleri Odası, Mimarlar Odası, Arkeologlar Derneği, Şehir Plancıları Odası, Fikir Sahibi Damaklar gibi meslek örgütü ve derneklerin de katkısıyla, bostancılık geleneğinin korunması konusunda ulusal ve uluslararası kamuoyu yaratmak için birçok etkinlik düzenlemiştir (bkz. TYBKG, 20I7). Bu süreçte Fatih Belediyesi projesinin iptali için yasal yollara da başvurulmuştur. Örneğin, 2013 yılındaki yıkımlar sırasında Arkeologlar Derneği İstanbul Şubesi, bostanlarda yapılan inceleme sonucunda müze denetimi olmadan kazı yapıldığını raporlayarak ilgili kurumlara iletmiştir (İnce, 2013). 20I4 yılında İstanbul Kara Surları Dünya Miras Alanı Koruma Sorunları İzleme Raporu - Tarih Yedikule Bostanları Üzerine Özel Bir İnceleme isimli Yedikule bostanlarının kara surlarıyla bir bütün olarak korunması gerektiğini savunan kapsamlı bir rapor hazırlanarak, UNESCO Dünya Mirası Merkezi, Kültür ve Turizm Bakanlığı Dünya Miras Alanları Şube Müdürlüğü ve İstanbul Sit Alanları Alan Yönetim Başkanlığı'na sunulmuştur.

8 IBB tarafından hazırlanmış olan bu projeye ait pafta ve görsellerin makale kapsamında kullanımına Kültür Varlıkları Projeler Müdürlüğü tarafından projenin Mart 20। 9 itibariyle revizyon aşamasında olduğu gerekçe gösterilerek izin verilmemiştir. Bu pafta ve görseller için bkz. Bozkurt, E. (20I7, 9 Haziran). ỉBB Yedikule Bostanlarına Dair Planını Açıkladı. http://www.arkitera.com/haber/289। I/ibb-yedikule-bostanlarina-dair-planini-acikladi. 

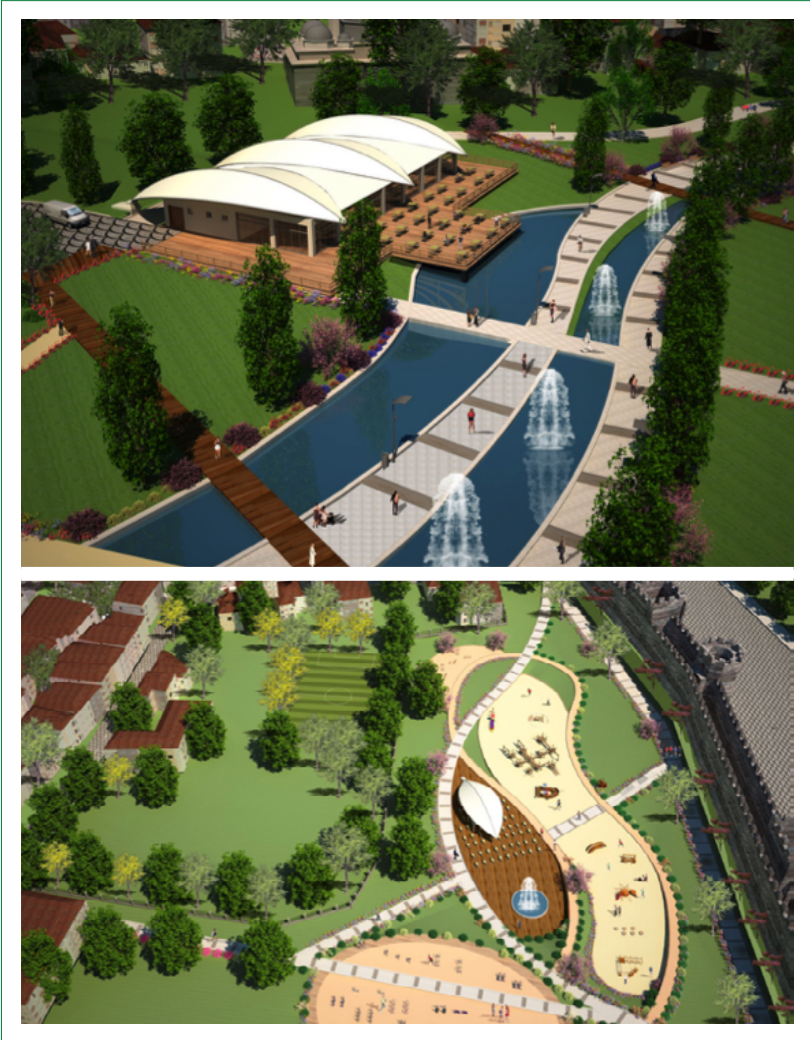

Şekil 9. Projede bostan alanlarının da bulunduğu bölgeye uygulanması planlanan şehir parkından süs havuzu, otopark, kafe, yürüyüş yolları vd. (Kaynak, http://kutupmimarlik.com/portfolio/kule-meydani-yedikule-kapi-ile-belgrad-kapi-arasi-kara-surlari-ic-koruma-alani-mimari-muhendislik-ve-rekreasyon-alani -uygulama-projesi/ [Erişim tarihi: 02.03.2019]

sağlanacağı ve pazar alanı, tohum bankası, kütüphane, tarım atölyeleri ve bostanlara yönelik eğitimlerin düzenleneceği ya da tanıtıcı ürünlerin satılacağı mekanlar oluşturulacağı belirtilir. Özet olarak, "bostan kültürünü" bostancılar olmadan korumayı amaçlayan bu projede de bostancılık bir zanaat olarak tanınmamış, bu geleneğin taşıyıcıları ve aktarıcıları olan bostancılar projenin planlama ve uygulanma süreçlerine dahil edilmemiştir.

Projenin 2017 yılında IBB Meclisi tarafından onaylanmasının akabinde moloz döküldükten sonra atıl duruma gelen eski bostan alanının temizlenmesi ve düzenlenmesi çalışmalarına başlanmıştır (Şekil II). Ancak bu çalışmalar da bir süre sonra kamuoyuyla paylaşılmayan nedenlerle durdurulmuştur ve projenin akıbeti hakkında net bir bilgi sahibi olunamamaktadır (Şekil 12). Temmuz 2018 itibariyle, Yedikule'de büyüklükleri ortalama beş ila on beş dönüm arasında değişen ve üçü suriçinde yirmi yedisi sur dışında bulunan, toplam otuz bostan
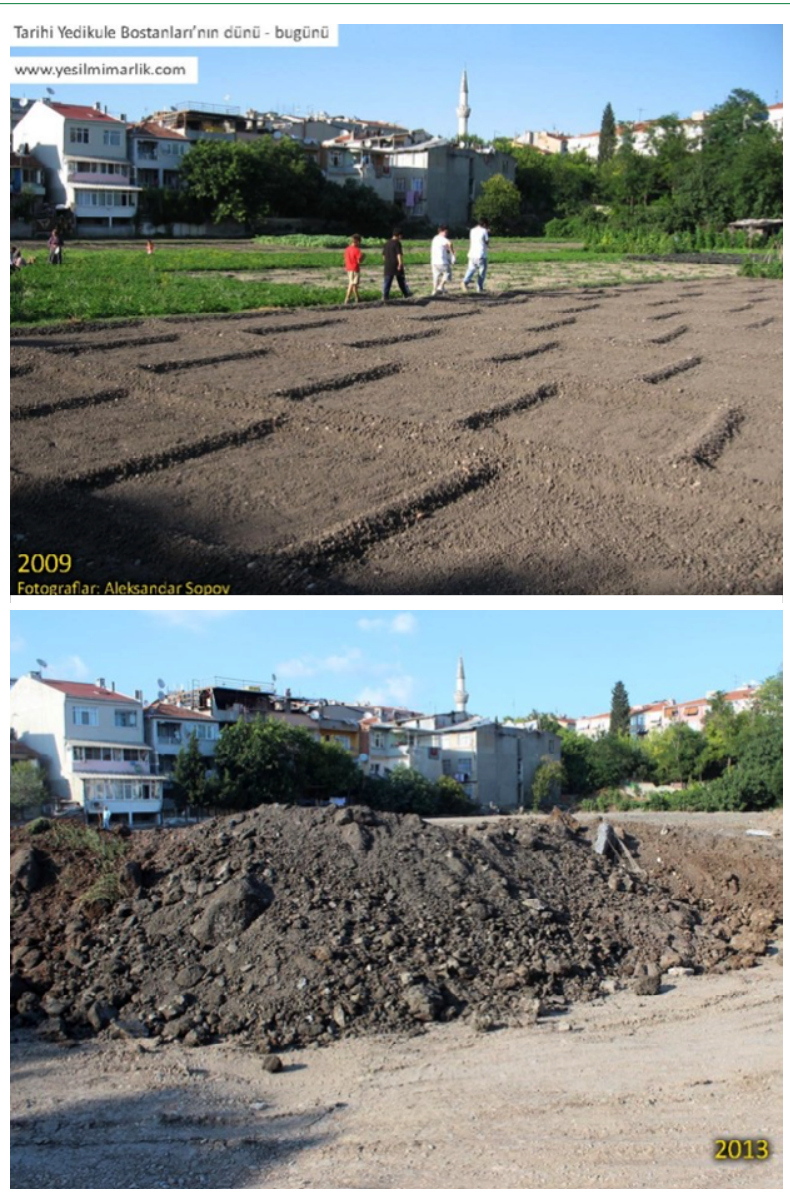

Şekil 10. Kara surlarının iç kısmında yer alan bostan alanlarının 2013'te moloz döküldükten sonraki durumu.

(A. Sopov'un izni dogrultusunda kullanılmışır)

faaliyet göstermektedir. ${ }^{9}$ Suriçindeki iki bostan ve sur dışındaki bostanlar yukarıda bahsedilen projelere dahil edilmemiş olsa da, gelecekte bu alanın da yeni bir projeyle yeşil alana dönüştürüleceğine dair kaygılar dile getirilmektedir (Aksoy, 2016). Nitekim sur dışındaki bostancılara ait barakalar IBB zabıtaları tarafından 2016 yııında yıkıımışır. Ayrıca, yakın zamana kadar orta sınıf bir gelir düzeyine sahip olan Yedikule bostancılarının gelirlerinde, diğer çiftçiler gibi devlet yardımlarından yararlanamamaları, iBB'ye işgalci statüsünde ödedikleri ecrimisil tazminatları ${ }^{10}$ ve tezgâh açıp ürünlerini satmalarına izin verilmemesi gibi nedenlerden dolayı, son yıllarda ciddi bir düşüş olmuştur.

Bu makale, Yedikule bostan geleneğinin sürdürülebilmesi için öncelikle bostancılık zanaatının Somut Olmayan Kültürel Miras olarak tanınması gerektiği savından yola çıkarak, kara surlarıy-

9 Özkan Ökten, 02.03.20I8 tarihli görüşme.

10 Yedikule bostanlarının bulunduğu alan İBB'ye aittir. Bostancılar belediye tarafından kiracı değil işgalci statüsünde kabul edildiklerinden dolayı ỉBB'ye yıllık ecrimisil tazminatı ödemektedirler. Hazine Taşınmazlarının İdaresi Hakkında Yönetmeliğin (2007) 4. maddesine göre ecrimisil, "hazine taşınmazının, İdarenin izni dışında gerçek veya tüzel kişilerce işgal veya tasarruf edilmesi sebebiyle, İdarenin bir zarara uğrayıp uğramadığına veya işgalcinin kusurlu olup olmadığına bakılmaksızın, taşınmazın işgalden önceki hâliyle elde edilebilecek muhtemel gelir esas alınarak İdarece talep edilen tazminat" olarak tanımlanmaktadır. Bkz: http://www.resmigazete.gov.tr/eskiler/2007/06/20070619-3.htm. Daha ayrıntılı bir tartışma için bkz. Sezer, 2004. 


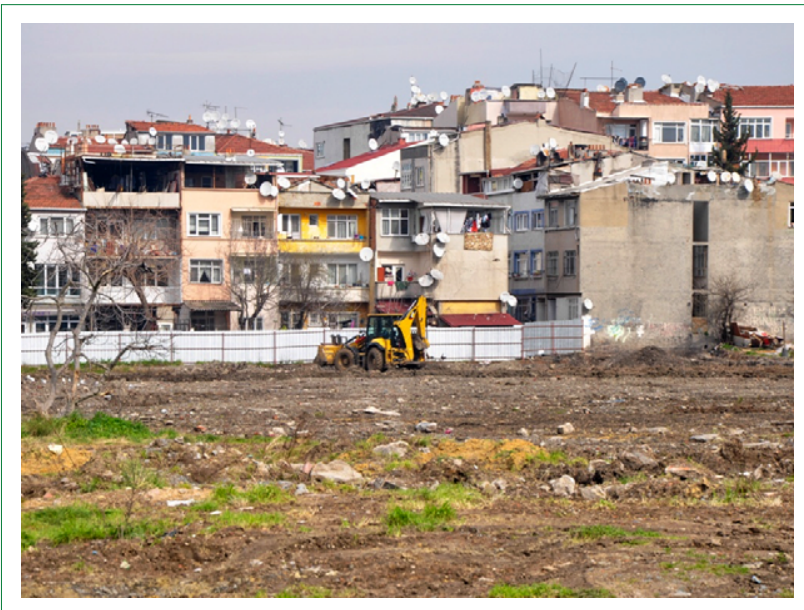

Şekil I I. 2017 yılında IBB tarafından onaylanan proje sonrasında moloz dökülen alanda yapılan düzenleme çalışması.

(Yazara ait, 02.03.18)

la bir bütün olarak ele alınıp korunmasına yönelik UNESCO Dünya Mirası Sözleşmesi nezdinde atılabilecek adımları tartışmayı amaçlamaktadır. 1950’lerden bugüne UNESCO sözleşmelerine bakıldığında "miras" kavramının kapsamının öneml ölçüde değişikliğe uğradığı ve tarihi anıtlar, eserler, binalar gibi fiziksel kültürel miras unsurlarını korumaya yönelik çabaların, zamanla doğal miras, kültürel peyzaj ve son olarak da Somut Olmayan Kültürel Mirası kapsayacak şekilde genişletildiği görülmektedir." 1954 tarihli Silahlı Bir Çatışma Halinde Kültür Mallarının Korunmasına dair Sözleşme, UNESCO'nun uluslararası düzeyde kültürel mirası korumaya yönelik ilk çabasıdır. Sözleşme, İkinci Dünya Savaşı sırasında anıtlar, arkeolojik ve sanatsal eserler gibi kültür varlıklarının uğradığı tahribat göz önüne alınarak onların silahlı çatışma anında zarar görmesini engellemeyi amaçlar (Blake, 2000, s. 6I). ${ }^{12}$

1972 yılında yürürlüğe giren Dünya Mirası Sözleşmesi ise anıtlar, bina grupları ve sit alanları olarak tanımlanan kültürel mirasın yanında doğal mirasın da uluslararası düzeyde korunmasına yöneliktir. UNESCO'nun en popüler ve ses getiren programlarından biri olarak kabul edilen sözleşme (Silverman, 20II), birçok ulusal ve yerel koruma programına öncülük ettiği gibi, Dünya Mirası kavramının uluslararası

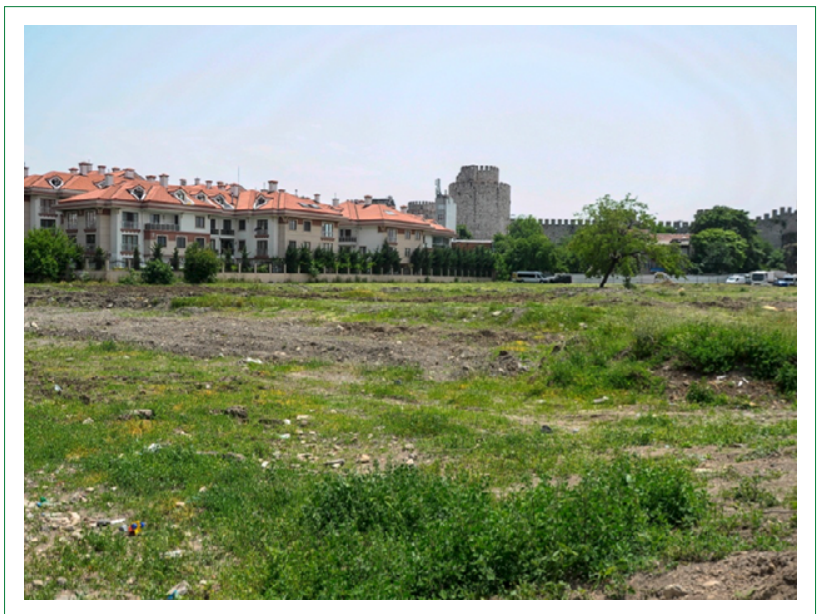

Şekil I2. Kamuoyuyla paylaşılmayan gerekçelerle durdurulan çalışmalar sonrasında alandan bir görünüm.

(Yazara ait, 24.05.18)

düzeyde tanınmasında ve bu mirasın gelecek kuşaklara aktarılması gereken bir değer olduğu fikrinin yaygınlaşmasında da etkili oldu. Ancak özellikle 1980'lerin sonundan itibaren bazı mesleki ve akademik çevrelerce Avrupa merkezli bir koruma anlayışını sanki evrensel bir koruma anlayışıymış gibi sunması ve bu bağlamda (mimarı yapılar, anıtlar, arkeolojik sit alanları gibi) kültürel mirasın somut özelliklerini ön plana çıkarırken, (sözlü gelenekler, ritüeller, gösteri sanatları, geleneksel inanç, bilgi ve beceri biçimleri gibi) somut olmayan değerleri göz ardı etmesi ve kültürel mirasa bütüncül bir yaklaşım getirememesinden dolayı eleştirilere uğradı. ${ }^{13}$

Bu konudaki en yeni (ve en önemli gelişme) kuşkusuz 2006 yılında yürürlüğe giren UNESCO Somut Olmayan Kültürel Mirasın Korunması Sözleşmesidir. ${ }^{14}$ Ancak 1990’lardan itibaren Dünya Mirası Sözleşmesi nezdinde de somut olmayan kültürel mirası kapsamaya yönelik adımlar atılmıştır. Somut ve somut olmayan miras arasında dikotomik/hiyerarşik bir ilişki varsayması dolayısıyla Dünya Mirası Sözleşmesi'ne yöneltilen eleştiriler ve bu dikotomiyi kültürel peyzaj yaklaşımıyla ortadan kaldırmaya yönelik çabalar bir sonraki bölümde ele alınacaktır. Üçüncü bölümde ise, Yedikule bostancılarıyla gerçekleştirilen yarı yapılandırılmış derinlemesine mülakatlar çerçevesinde bostancılık zanaatının geleneksel yöntem ve

"Detaylı bir tartışma için, bkz. Ahmad, 2006.

12 1970'lere kadar UNESCO'nun kültürel mirası koruma çabaları, tarihi eser kaçakçılığının engellenmesi, arkeolojik kalıntıların korunması ve yenileme ve bakım çalışmaları sırasında kültürel mirasın zarar görmemesi hakkında sözleşmeler ve tavsiye kararları ile sınırlı kaldı. Bkz: Arkeolojik Kazılara Uygulanabilir Uluslararası Prensipler Hakkında Tavsiye Hararı (1956); Kamusal veya Özel Yapım Çalışmalarınca Tehdit Edilen Kültürel Varlıkların Korunmasına İlişkin Tavsiye Kararı (I968); Kültürel Varlıkların Yasadışı İthalatının, İhracatının ve El Değiştirmesinin Yasaklanması ve Önlenmesi Sözleşmesi (1970). Daha ayrıntılı bir tartışma için bkz. Aykan, 2012.

13 Bkz: Fowler, 2003; Smith, 2006; Taylor ve Altenburg, 2006; Beazley ve Deacon, 2007; Rössler, 2006.

14 UNESCO nezdinde somut olmayan kültürel mirası korumaya yönelik adımlar 1970'lerde atılmaya başlanmıştır. 197I yılında Folklorun Korunmasına Dair Uluslararas Sözleşme Hazırlama Olasılığı isimli bir belge hazırlanmış, 1976 yılında UNESCO “Kapsamlı Somut Olmayan Kültürel Miras Programı” başlatılmış ve I 978 yılında da Dünya Fikri Mülkiyet Örgütü ile folklorun korunmasına yönelik ortak bir çalışma yürütülmüștür (Sherkin, 200I; Lixinski, 20I3: 30). 1982 yılında UNESCO bünyesinde kurulan Folklorun Korunmasına İlişkin Uzmanlar Komitesinin çalışmaları neticesinde UNESCO 1989 yılı Genel Konferansında Folklorun ve Geleneksel Kültürün Korunması Tavsiye Kararı almıştır (Sherkin, 200I). Bu tavsiye kararının ardından 1997 yılında İnsanlığın Sözlü ve Somut Olmayan Kültürel Mirasının Başyapıtları programı başlatılmıştır ve bu süreç Somut Olmayan Kültürel Mirasın Korunması Sözleșmesine zemin hazırlamıştır. İşleyiş ve uygulama bakımından Dünya Mirası programına oldukça benzerlik gösteren bu sözleşme, Somut olmayan mirasa topluluk temelli bir yaklaşım getirerek, onu topluluklara, gruplara ve kimi durumlarda bireylere "kimlik ve devamlılık duygusu" veren "uygulamalar, temsiller, anlatımlar, bilgiler beceriler ve bunlara ilişkin araçlar, gereçler ve kültürel mekanlar" olarak tanımlar (UNESCO, 2003). Mart 20।9 itibariyle I 22 ülkeden 508 kültürel pratiği listelerinde bulunduran sözleşme, I 78 ülke tarafından imzalanmıştır. Sözleşmenin ortaya çıkış süreci ve kapsamı konusunda tartışma için, bkz. Hafstein, 2009. 
özelliklerine odaklanılarak, ${ }^{15}$ bostanların kara surlarını çevreleyen bahçeler ya da yeşil alanlar olarak değil, kuşaktan kuşağa aktarılarak sürdürülen bir bilgi ve beceri mirasının somutlaşmış hali olarak tanınması ve kara surlarıyla bir bütün olarak korunması gerektiği tartışılacaktır. 1992 yılında kültürel peyzaj kategorisinin dünya mirası olarak tanınması, daha önce sadece somut kültürel miras özellikleri dolayısıyla listelenen unsurların (mevcut ise) somut olmayan kültürel miras özellikleriyle birlikte korunabilmesini mümkün kılmıştır. Böylelikle, dünyanın farklı bölgelerinde geleneksel yöntemlerle sürdürülen tarım faaliyetleri de kültürel peyzajın bir alt kategorisi olan gelişimini sürdüren organik peyzaj olarak dünya mirası listesine dahil edilmiştir. ${ }^{16} \mathrm{Bu}$ bağlamda, sonuç bölümünde bostancılık geleneğinin yaşatıldığı alanların da I. Derece Koruma Bölgesi olarak Dünya Mirası statüsüne alınması ve kara surlarıyla birlikte gelişimini sürdüren organik peyzaj olarak yeniden listelenmesi değerlendirilecektir. Böyle bir değişikliğin bostancılığın sürdürülmesi konusunda ulusal ve uluslararası kamuoyu oluşmasına ve bostancıların bu mirasın taşıyıcıları olarak desteklenerek karar alma süreçlerine dahil edilmesi yönünde politikalar ve projeler geliştirilmesine katkı sağlayacağı düşünülmektedir.

\section{Dünya Mirası Sözleşmesi ve Somut/Somut Olmayan Kültürel Miras Dikotomisi}

Kültürel miras koruma süreci geçmişin bazı kültürel unsurlarına değer yüklerken diğerlerini göz ardı eden, dışlayıcı bir süreçtir (Byrne akt. Byrne, 2009, s. 230.). lan Hodder (2010, s. 863 ) bu durumu şöyle açıklar:

Tüm toplumlar kendi mirasını yok eder. Britanya'da veya Amerika Birleşik Devletleri'nde arabayla dolaşırken yeni araziler için evlerin yıkıldı̆ı̆na, yeni yüksek hızlı otoyolların inşa edilebilmesi için yolların kazıldığına, ormanların yok edildiğine, eski ahırların çürümeye terk edildiğine, fabrika bacalarının yıkıldığına ve artık kullanılmayan santrallerin parçalandığına şahit olabilirsiniz. Yine de bu eserlerden bazıları korunur ve santraller bile sanat galerilerine dönüştürülebilir (örneğin Londra'daki Tate Modern). Geçmişin sadece seçilmiş bir kısmını saklar ve koruruz.

Hangi kültürel unsurların miras olarak seçilip korunacağı ise güncel sosyo-politik ve ekonomik amaç ve ihtiyaçlar doğrultusunda belirlenir. Kültürel mirasın, geçmişe dayanan ortak bir kimlik olgusu oluşturmak; azınlıklar, yerel haklar ve göçmenler gibi dezavantajlı grupların kimliklerini ve kendilerini tanımlama biçimlerini görmezden gelmek veya dışlamak; ya da kültür turizmi kapsamında ekonomik bir kaynak olarak kullanmak gibi çeşitli amaçlara hizmet verdiğini tartışan geniş bir literatür oluşmuş durumdadır. ${ }^{17}$ Kültürel mirasın toplumsal yapı ve ilişkilerden bağımsız düşünülemeyeceği savından hareketle Laurajane Smith (2006, s. II), “Resmi Miras Söylemi” kavramını kültürel miras konusundaki güncel düşünme biçimlerini, politikaları ve pratikleri şekillendiren hegemonik söylem olarak tanımlar. Batı/Avrupa merkezli bir kültürel miras anlayışını sanki evrensel bilimsel ve estetik bir değermiş gibi sunan bu söylem, ${ }^{18}$ "anıtsal" ve "mimari açıdan estetik" olanı kültürel miras olarak seçip korumaya yönelir:

Mirasın somutluğu fikrine bağlı olan bir fikir de onun 'sınırlandırılmışlığıdır'. AHD [Resmi Miras Söylemi] içinde miras geleneksel olarak işaret edilebilir sınırları olan, haritalanabilen, ölçülebilen, kaydedilebilen ve ulusal veya uluslararası listelere işlenebilen ayrık bir 'alan', 'nesne', bina veya başka bir yapı olarak düşünülegelmiştir. (Smith, 2006, s. 3I.)

Somut ve somut olmayan kültürel miras arasındaki dikotomik/ hiyerarşik ilişki de işte bu bağlamda ortaya çıkar. Çünkü bu söylem kültürel mirasın sadece maddi özelliklerine odaklanıp, onların korunmasına yönelik politikalar geliştirir. Halbuki Smith'e göre bir objeyi, yapıyı ya da alanı kültürel miras yapan şey temelde ona atfedilen toplumsal değer ve anlamlardır. Bu bağlamda, kültürel miras özünde soyut bir olgudur:

...mirasın uluslararası sınıflandırılmasında ayrı ayrı şeyler olarak önce 'mirası' tanımlamak ve sonra 'somut olmayan mirası' tanımlamak gibi üzerinde anlaşılmış bir eğilim vardır. Benim buradaki görevim ise sadece bu iki miras kavramın 'somut olmayan mirasın' da basitçe 'miras' olarak düşünüleceği şekilde bir araya getirmek değil, aynı zamanda tüm mirasları öncelikle özünde somut olmayan olarak tekrar tanımlamak. Yani, gerçekten yönetim ve muhafaza/koruma uygulamalarının öznesi olan ve ziyaretçilerin, turistlerin miras alanlarında muhatap oldukları şeyler aslında bu miras alanları veya kültürel uygulamaların simgelediği ya da temsil ettiği değerler ve anlamlardır. Mirasın alısıllagelmiş 'somut' veya 'somut olmayan' temsilleriyle ilgileniyor olalım ya da olmayalım, aslında duygu, hafiza ve kültürel bilgi ve tecrübe gibi öğeleri kapsayan bir değerler ve anlamlar kümesiyle muhatap oluyoruzdur. Miras muhafaza ve

\footnotetext{
${ }^{15}$ 05.20।7-16.06.20I8 tarihleri arasında beş bostancı ile dokuz görüşme gerçekleştirilmiştir. Kar topu yöntemi kullanılarak farklı bostancılara ulaşılmaya çalışılmış, ancak bu kişilerin bir kısmı görüşme konusunda isteksiz davranarak araştırmacıları Yedikule Bostancılar Derneği Başkanı Özkan Ökten'e yönlendirmiştir. Bostancıların Yedikule'deki gelişmelerden rahatsız olması dolayısıyla kendisini "sözcü” olarak seçtiklerini belirten Ökten ile üç derinlemesine mülakat gerçekleştirilmiş ve bu görüşmelerde Yedikule'deki bostancılar ve bostancılık geleneği üzerine daha kapsayıcı bilgiler edinilmeye çalışılmıştır. Araştırmaya katılmayı kabul eden diğer dört bostancı ile de altı derinlemesine mülakat yapılmıştır. Bostancılarla görüşmelerin yanında, ilgili İBB personeli ile iki, İstanbul Sit Alanları Alan Yönetim Başkanlığı personeli ile bir, Tarihi Yedikule Bostanlarını Koruma Girişimi üyeleri ile de iki derinlemesine mülakat gerçekleştirilmiştir. Ökten haricindeki katılımcıların isteği doğrultusunda kimlik bilgileri sakl tutularak gerçek isimleri yerine takma isimler kullanılmıştır.

16 Örneğin, Cordilleras Pirinç Terasları (Filipinler, 1995); Portovenere, Cinque Terre ve Palmaria, Tino ve Tinetto Adaları teraslı tarım arazileri (Italya, I997); Kahve Kültürel Peyzajı (Kolombiya, 20II); Grand Pré Peyzajı (Kanada, 20I2).

17 Bkz: Hall, 2005; Graham ve Howard, 2008; Anico ve Peralta, 2009; Hodder, 20I0; Lixinski, 20I0; Logan, 20I0; Logan, Langfield ve Craith, 20I0; Swanson ve Timothy 2012; Di Giovine, 2014; Sammells, 2014.

${ }_{18}$ Örneğin, "miras” kavramının İngilizce dilindeki 13. yüzyıla ait bilinen ilk kullanımı sadece fiziksel taşınmazları ya da somut objeleri kapsar (Baillie ve Chippindale, 2007, s. I76)
} 
yönetim süreçlerinin gerçek özneleri değer ve anlamdır ve bu yüzden bu değer ve anlam fiziksel bir alan, yer, peyzaj veya başka bir fiziksel temsille simgelensin veya simgelenmesin, tüm miraslar 'somut olmayan' mirastır. (Smith, 2006, s. 56)

Dolayısıyla, somut mirasın kendinden menkul bir önemi, anlamı ya da estetik güzelliği yoktur. Bir obje veya mimari yapı somut olmayan değerler, pratikler ve kullanımlar aracılı̆̆ı ile anlam kazanır (Beazley ve Deacon, 2007, s. I). Taylor ve Alterburg'a (2006, s. 267) göre onu yaşadığı ve yaşatıldığı geniş tarihi ve kültürel bağlama oturtarak ele almayan bir yaklaşım, "ağacın yapraklarını görüp gövdesini görmemek" gibidir. Somut olmayan miras ise kalıcı ve sabit bir cisme bürünmeden de varlığını sürdürebilir (Beazley ve Deacon, 2007, s. I); ancak sözlü, yazılı ya da uygulamalı olarak somutlaştırılmadan yaşatılamaz ve aktarılamaz. Ayrıca, kültürel pratikler varlıklarını sürdürdükleri mekân ya da yapı ile ilişkilerini yitirdiklerinde anlamları da değişebilir veya kaybolabilir. Örneğin, Mevlevihane dışında yapılan Sema bir ritüel ya da tören olarak değil, gösteri olarak kabul edilir (Aykan, 2010). Özetle, somut kültürel mirası etrafında oluşan ritüellerden, pratiklerden ve anlatma biçimlerinden, somut olmayanı ise maddi bağlanımdan kopararak kavramak mümkün değildir (Metin Basat, 20I3, s. 62). Kültürel miras hem somut hem de somut olmayan özellikler barındırdığından, bu özellikleri ve onların ilişkilerini bütüncül bir şekilde ele alan, kapsayıcı bir yaklaşımla korunmalıdır.

Smith (2006, s. 94-102), Dünya Mirası Sözleşmesi'ni, bu bütüncül yaklaşımı göz ardı etmesi dolayısıyla eleştirir. Sözleşme kültürel mirası tanımlarken özellikle taşınmaz kültür varlıklarına odaklanır. Sözleşmenin I. Maddesine göre dünya kültürel mirasını tarih, sanat veya bilim açısından istisnai evrensel değeri olan anıtlar (mimari ve arkeolojik yapılar, mağaralar, heykel ve resim alanındaki şaheserler ve kitabeler); mimari, uyumluluk veya konumları nedeniyle istisnai evrensel değere sahip yapı toplulukları; ve sitler (insan ürünü veya insan ve doğanın ortak ürünü eserler ve arkeolojik sit alanları) oluşturur (UNESCO, 2008, 45). Bu anıtlar, yapı toplulukları ya da sitler çevreleriyle bir bütün olarak değil, çoğu zaman münferit olarak, yani bağlamlarından koparılıp kültürel peyzajları dikkate alınmayarak, listelenmiş ve korumaya alınmıştır (Fowler, 2003, s. 15).

Maddi bir forma bürünmemiş sözlü gelenekler, ritüeller, gösteri sanatları, geleneksel bilgi ve beceri biçimleri gibi kültürel değerlerin korunması bu sözleşmenin önceliği değildir. Bir unsurun Dünya Mirası Listesi'ne kabul edilebilmesi için belirlenmiş kriterler de kültürel mirasın istisnai evrensel değerini açıklarken yapı tipleri, anıtlar, arkeolojik kalıntılar ve tarihi eserler gibi somut kültür varlıklarını önceler (UNESCO, 1988, 23-24). Aslında, bu kriterler kültürel mirasın somut olmayan özelliklerine de değinir. Örneğin, beşinci kriter yok olma tehlikesi altındaki bir kültürün üstün örneği olan geleneksel insan yerleşimlerini istisnai evrensel değer kabul eder. Altıncı kriter ise dünya mirasının somut olmayan özelliklerine daha net bir vurgu yapar ve istisnai evrensel değer taşıyan "olaylar, fikirler ve inanışların” somutlaştığı kültür varlıklarını içerir. Ancak burada da yaşatılması amaçlanan bu inançlar ya da fikirler değil, onların cisim bulduğu kültür varlıklarıdır. Ayrıca, altıncı kriterin tercihen diğer kriterle birlikte kullanılması gerekmektedir. Mart 2019 itibariyle toplam 1092 kültürel unsurun bulunduğu Dünya Mirası Listesi'ne yalnızca altıncı kriteri sağladığı için dahil edilen unsur sayısı sadece on ikidir.

Koruma süreçlerinde kültürel mirasın somut biçimlerini ön plana çıkarırken somut olmayan değerleri göz ardı eden bu yaklaşım, uygulamada da birçok sorunu beraberinde getirdi. Öncelikle, aşağıda daha detaylı bir şekilde ele alacağımız gibi, somut/somut olmayan dikotomisini ortadan kaldırmaya yönelik adımlar atılmaya başlandığı 1992 yılına kadar, sözleşme nezdinde Somut Olmayan Kültürel Mirası korumaya yönelik politikalar ve uygulamalar geliştirilemedi. Kültürel varlıklara yapılan bu vurgu ayrıca, Asya ve Afrika gibi, kültürel mirasın somut olmayan özelliklerinin öne çıktığı bölgelerin Dünya Mirası Listesi'nde yetersiz temsil edilmesine yol açarken, kaleler, kiliseler ve katedraller gibi Avrupa'nın taşınmaz kültür varlıklarının listede ağırlık kazanmasına neden oldu (Barthel-Bouchier, 2016). Örneğin, dünya kültürel mirasının halen yaklaşık \%52'si Avrupa ve Kuzey Amerika'da bulunmaktadır. Listede Afrika'dan 52, Asya ve Pasifik bölgesinden 181, Avrupa ve Kuzey Amerika'dan ise 440 kültürel varlık yer alır. Kültürel mirasa anlam veren gelenek, deneyim ve pratiklerin dikkate alınmaması dolayısıyla dünya mirasının “insansızlaştırılarak” korunmasına yönelik politikalar da yaygınlaştı. Bu politikaların, kültürel mirası anlamlandıran, kullanan, yaşayan ve yaşatan grupların dünya mirası alanlarından zorunlu tahliye edilmesine ya da yönetim süreçlerine dahil edilmemesine yol açan uygulamalarını eleştirel bir bakış açısıyla ele alan zengin bir literatür bulunuyor. ${ }^{19}$

Dünya Mirası Komitesi somut/somut olmayan miras dikotomisinin uygulamada doğurduğu eşitsizlikleri dikkate alarak 1992 yılında "doğa ve insanın ortak eserlerini” temsil eden kültürel peyzaj kategorisini de dünya mirası olarak tanıyıp koruma altına alma kararı verdi. Bu amaçla bir kültürel unsurun istisnai evrensel değerini ölçen altı kriterden beşi kültürel peyzajı da kapsayacak bir şekilde değiştirildi (Tablo I). Fowler'in belirttiği gibi (2003, s. I5), burada amaçlanan mevcut kriterlere göre değerlendirilemeyen unsurların da aday gösterilmesine olanak sağlamaktır; dolayısıyla kültürel peyzaj kategorisinin kabul edilmesi sözleşmenin işleyiş mekanizmalarında kavramsal ya da metodolojik olarak radikal bir değişime işaret etmez. Ancak makalenin ilerleyen kısımlarında detaylandırılacağı üzere, bu kategorinin eklenmesi yerel toplulukların dünya mirası alanlarının yönetimine ve karar alma süreçlerine katılımına olanak sağlamıştır.

19 Bkz: Miura, 2005; Jalais, 2007; Suman, 2008; Chirikure vd., 2010; Meskell, 20I0; Logan, 2014. 
Tablo I. Kültürel peyzaj kategorisinin kabul edilmesiyle dünya miras kriterlerinde yapılan değişiklikler altı çizili olarak belirtilmiştir
i. İnsanın yaratıcı dehasının üst düzeyde bir temsilcisi olmak
ii. Dünyanın bir kültür bölgesinde veya bir zaman sürecinde mimarlık veya teknoloji, anıtsal sanatlar, kentsel planlama veya peyzaj tasarımı alanlarında önemli gelişmelere ilişkin insani değerlerin alışverişine tanıklık etmek
iii. Yaşayan ya da yok olmuş bir kültür geleneğinin veya uygarlığın istisnai ya da en azından ender rastlanan bir temsilcisi olmak iv. İnsanlık tarihinin önemli bir aşamasını (veya aşamalarını) gösteren bir yapı tipinin mimari ya da teknolojik bütünün veya peyzajın istisnai bir örneği olmak
v. Özellikle geri dönülmez bir değişimin etkisi altında zedelenebilir olan bir kültürün (veya kültürlerin) ya da çevre ile insan etkileşiminin temsilcisi olan, geleneksel insan yerleşimi, arazi kullanımı veya deniz kullanımının istisnai bir örneği olmak
vi. İstisnai evrensel önem taşıyan sanatsal veya edebi eserler, inançlar, fikirler, yaşayan gelenekler ve olaylarla doğrudan veya dolaylı olarak bağlantılı olmak (Komite bu kriterin tercihen diğer kriterler ile birlikte kullanılması gerektiğini dikkate alır)

Sözleşmenin uygulama rehberine göre bu kategoride listelenen unsurlar, "hem iç hem de dış ardışık sosyal, ekonomik ve kültürel güçlerin etkileri ve doğal çevrelerinin ortaya koyduğu fiziksel kısıtlamalar ve/veya fırsatların etkisi altında zaman içinde insan toplumlarının ve yerleşimlerinin evriminin" örneklerini oluşturur (UNESCO, 2008, 47). Kültürel peyzaj olarak listelenebilecek çeşitli unsurların neden koruma altına alınması gerektiği ise şu şekilde açıklanır:

Bazı alanlar biyolojik çeşitliliği garanti eden ve sürdüren özel arazi kullanım tekniklerini yansıtıllar. Diğerleri, toplulukların zihinlerinde güçlü inançlar ve sanatsal ve geleneksel davranıslarla özdeşleşerek, doğayla insanlar arasında istisnai bir ruhani ilişkiyi somutlaştırılar. Insanlar ve çevreleri arasındaki muhteşem çeşitliliği ortaya çıkarmak ve sürdürmek, yaşayan geleneksel kültürleri korumak ve yok olmuşların izlerini korumak amacıyla, kültürel peyzaj olarak adlandırılan bu alanlar Dünya Mirası Listesi'nde kayıt altına alınmıştır. Kültürel peyzaj alanları - yüce dağların üstündeki ekip biçilen düzlükler, bahçeler, kutsal mekanlar... - insanlı̆ı̆n yaratııı dehasına, sosyal gelişimine ve imgesel ve ruhani canllığına şahitlik etmektedir. Bunlar bizim kolektif kimliğimizin parçasıdır. (UNESCO, 2008, 47)

Sözleşme, kültürel peyzajı insan eliyle tasarlanmış peyzaj, organik olarak gelişmiş peyzaj ve ilişkisel kültürel peyzaj olarak üç alt kategoriye ayırır (UNESCO, 2018b). İlk kategori, insanlar tarafından kasten yaratılmış ve tasarlanmış bahçeler, park alanları ve bunlarla bir arada bulunan anıtsal yapı ve yapı gruplarından oluşur. Organik olarak gelişmiş peyzaj ise zaman içinde sosyal, ekonomik, idari veya dini zorunluluklar nedeniyle oluşmuş, doğal çevresiyle girdiği ilişki dolayısıyla günümüzdeki halini almış ve bu ilişkilerin evrimini ve değişimini ortaya koyan alanlar olarak tanımlanır. Bu kategori de kendi içerisinde, geçmişte gelişme süreci sona ermiş ama ayırt edici özelliklerini hala koruyan relikt (fosil) peyzaj ve gelişimini sürdüren organik peyzaj, yani geleneksel yaşam biçimleriyle ilişkilendirilen ama toplumdaki aktif sosyal rolü devam eden ve aynı zamanda kendi tarihsel değişi- mine dair önemli somut kanıtlar sergileyen peyzaj, olarak ikiye ayrılır. Güçlü dini, artistik ya da kültürel bağlar taşıyan ancak bu bağların varlığına dair önemli somutlaşmış kanıt bulundurmayan ilişkisel kültürel peyzaj alanları da son kategoriyi oluşturur.

Dünya Mirası'nı anlamlandıran yaşam dinamiklerini ve onu günümüze taşıyan sosyal bağlamları ve tarihsel değişimleri dikkate alan bu adım, ilgili literatürde de olumlu bir gelişme olarak karşılandı. Örneğin, Rössler’a göre (2006, s. 334) somut ve somut olmayan mirasın iç içe geçmiş ilişkisini tanıyan kültürel peyzaj kategorisinin kabul edilmesi, Dünya Mirası Sözleşmesi'nde insansız ve statik bir kültürel miras koruma anlayışından, insan ve toplulukları ön plana çıkaran daha dinamik bir anlayışa doğru önemli bir perspektif değişimine işaret eder. Beazley ve Deacon (2007) ise özellikle Dünya Mirası'nın somut olmayan özelliklerini ön plana çıkaran ilişkisel kültürel peyzaj kategorisinin somut/somut olmayan dikotomisini ortadan kaldırmada önemli bir adım olduğunu belirtir. Bu kategorinin kabul edilmesi, insanların ya da toplulukların çeşitli sosyal nedenlerle güçlü bağlar kurduğu ama bu bağların anıtsal ya da mimari tasarımlara dönüşmediği mekanların, onlarla ilişkilendirilen somut olmayan değerlerden ötürü, Dünya Mirası olarak değerlendirilmesini mümkün kılar (Beazley ve Deacon, 2007, s. 6). Bu değerlerin tanınması ve koruma altına alınması aynı zamanda onları yaşayan ve yaşatan grupların da tanınarak yönetim süreçlerine dahil edilmesinin önünü açar. Beazley ve Deacon $(2007$, s. 7) bu duruma örnek olarak Tongariro (Yeni Zelanda) ve Uluru Kata Tjuta (Avustralya) doğal parklarını verir: daha önce doğal miras olarak listeye alınmış olmalarına rağmen, kültürel peyzaj kategorisinin kabul edilmesiyle bu parklar yerel halklar tarafindan onlara atfedilen kültürel ve tinsel değerlerden ötürü, ilişkisel peyzaj özellikleri dikkate alınarak, yeniden listelenmiştir.

Aktif olarak sürdürülen bir tarım geleneğin maddi kanıtını oluşturması nedeniyle gelişimini sürdüren organik peyzaj olarak listelenen unsurların yönetim süreçlerinin de bu geleneğin taşıyıcısı olan toplulukların katılımıyla gerçekleştiği görülmek- 
tedir. Örneğin, 20II yılında listeye dahil edilen Kolombiya Kahve Kültürel Peyzajının yönetim komitesinde geleneksel yöntemlerle kahve üreten yerel çiftçi temsilcileri yer almaktadır (UNESCO, 2019a). Çiftçilerin sosyal ve ekonomik refahının öncelikli olduğunu vurgulayan dünya mirası yönetim planında, bu pratiğin sürdürülebilmesi için bölgede kimyasal ilaç ve gübre kullanımına karşı geleneksel tarım yöntemlerinin desteklediği ve yeniden yapılandırma ya da altın arama ve çıkartma gibi bu kültürel peyzaja zarar verecek projelere izin verilmediği belirtilir (UNESCO, 2019a). Benzer bir şekilde, 1995 yilında aynı kategori altında listelenen Filipin Cordilleras Pirinç Terasları, Ifugao yerel hakları tarafından müşterek olarak ve topluluğun geleneksel biyoçeşitlilik bilgi ve becerisi, yasaları, toprak kullanım teknik ve pratikleri göz önünde bulundurularak yönetilmektedir (UNESCO, 2019b).

Mart 2019 itibariyle, kültürel peyzaj kategorisinde 61 ülkeden 102 unsur bulunmaktadır. Ancak, doğal veya kültürel miras olarak listede bulunan birçok unsur aslında kültürel peyzaj kategorisinde değerlendirilmeli ve yeniden aday gösterilmelidir (Fowler, 2003; Taylor ve Altenburg, 2006). Bir sonraki bölümde detaylandırılacağı üzere, kara surları ve Yedikule bostanlarının oluşturduğu alan da bu unsurlardan biridir.

\section{Somut Olmayan Kültürel Miras Olarak Yedikule Bostancilık Geleneği}

Halen büyük ölçüde geleneksel tarım yöntem ve tekniklerin kullanıldığı Yedikule bostancılığı, Bizans'tan Osmanlı'ya oradan da günümüze kadar kuşaktan kuşağa aktarılarak ulaşmış yaşayan önemli bir bilgi ve beceri mirasıdır. Aslıhan Demirtaş'a göre, Bizans ve Osmanlı'nın ilk dönemlerinde çoğunlukla Rum ve Ermeniler bu bölgede bostancilık yaparken, bu gelenek daha sonra Arnavutlar tarafından öğrenilip devralınmıştır (Kılınç, 2017). Hem Bizans ve hem de Osmanlı dönemine ait kaynaklarında verimli ziraat alanları olarak kayıt edilen Yedikule bostanları hakkında kapsamlı bilgiye 1735 tarihli bir Kefil Defteri'nde rastlanır (Shopov ve Han, 2013, s. 36). ${ }^{20}$ Bu Kefil Defteri, suriçi boyunca uzanan 344 adet bostandan 9 tanesinin Yedikule ve Silivri Kapı arasında bulunduğunu ve suriçinde üretim yapan 138। bostancının 52 neferinin bu alanda çalıştığını belirtir (Shopov ve Han, 2013, s. 36). Bu bostancıların büyük çoğunluğu Makedonya bölgesinden gelen ve Slavca konuşan Hristiyanlardan oluşur (Shopov ve Han, 2013, s. 36). Yedikule'nin bugünkü bostancıları ise İstanbul'a iki-üç kuşak önce Kastamonu'nun Cide ilçesinden göç etmiş ve bu zanaatı yanlarında çalıştıkları Arnavutlardan öğrenmişlerdir:

1900'lerin başında buralarda işçilik yapıyor babalarımız, dedelerimiz daha doğrusu. [Cide'den] geliyorlar Arnavutların yanı- na, burada çalsşıorlar ... Zamanla Arnavutlar zenginleşince, buralarda pazarlar açıldığında ... başka işlere meylediyorlar. $\mathrm{Bu}$ iş de ağır olduğu için yanında çalışan adama diyor ki, işte Ahmet ben işi bırakıyorum. Şu işe giriyorum. Gel sana devredeyim burayı ... İşte o zamanın parası diyelim on lira, on beş lira, karşılı̆ında bostanı devrediyor ... O zamanda iki tane at var mesela. íki tane atla bahçeyi sürüyorsun, aynı kara saban bildiğin. İki atını, sabanını, tohumlarını, komple neyi varsa 0 döneme ait onları devrediyor sana adam. ${ }^{21}$

Dedelerinin bu zanaatı devraldıkları dönemde bostancilığın iyi gelir getirdiğini ancak günümüzde kâr marjının çok düştüğünü ve "zar zor geçinebilecek kadar" kazanç sağlayabildiklerini anlatan bostancılar, yine de bu mesleği bırakmayı düşünmediklerini, çünkü bostancıllğı bir işten öte bir yaşam biçimi olarak gördüklerini belirtmişlerdir. Bostancılığın hava koşullarına ve mevsimlere göre değişen kendine has ritmi onların gündelik hayatlarını büyük ölçüde şekillendirmektedir. Bostancılar ayrıca mesleklerinin İstanbul gibi büyük bir metropolde doğayla iç içe yaşayabilmelerine olanak sağladığını, toprakla uğraşmanın kendilerine huzur ve mutluluk verdiğini ve ürünleriyle kurdukları manevi bağın önemini vurgulamışlardır:

Ne var... yılların geçmiş... Yani ne diyeyim, şimdi bi ağaç, bir fidan, evlat gibidir benim gözümde... Onu büyütmek, işte onu sulamak, onun dalından meyvesini koparmak bile benim için çok önemli bir şey yani. $O$ parayla ölçülecek bir şey değil. ${ }^{22}$

Sabah oldu mu, hanım yataktan kalktığı zaman evden doğru buraya koşuyoruz. Hepsi burada yetişti çocukların ... Şimdi şöyle, direk bununla yoğrulmuşuz. Affedersin tohuma yem atmışlar yine boktaymış gözü, bizim de gözümüz burada. ${ }^{23}$

Küçük ölçekli tarım alanlarından maksimum ürün ve verim almaya dayalı bir üretim biçimi olan bostancılık, bu özelliğiyle tek ürüne dayalı monokültür tarımdan farklıdır. Bostanlarda İstanbul'un iklimine uygun olan her türlü sebze ve yeşillik yetiştirilir. Tarım faaliyetlerine sadece Aralık ortasından Şubat ortasına kadar ara verilir. Mevsimine göre turp, pırasa, patates, soğan, ıspanak, karnabahar, mor ve beyaz lahana, pancar, brokoli, havuç, kereviz, enginar, fasulye, domates, biber, patlıcan, bal kabağı ve yeşil kabak, maydanoz ve marul çeşitleri, nane, tere, kuzu kulağı, dereotu, reyhan, fesleğen, roka gibi birçok farklı ürünün ve çeşitlerinin üretimi on ay boyunca devam eder. Bu ürünler, MS. altıncı yüzyıldan itibaren yazımına başlanan ve bostanlarda farklı mevsimlerde yetiştirilecek sebze ve yeşillikler hakkında sistematik bilgi veren Bizans metni Geoponika ile de büyük oranda örtüşmektedir (Ricci, 2008, s. 66-67).

\footnotetext{
${ }^{20}$ Ayrıca, I7-19 yüzyıl arasında İstanbul bostanları ve bostancıları hakkında ayrıntılı bir çalışma için bkz., Akdal, 2017.

21 Özkan Ökten, 02.03.2018 tarihli görüşme

${ }^{22}$ Kemal Bey. 20.05.2018 tarihli görüşme

${ }^{23}$ Cemal bey. 20.05.2018 tarihli görüşme
} 
Bostanlara düzenli olarak gidip gelmeleri gerektiğinden bostancıların hepsi Yedikule mahallesinde ya da civar semtlerde ikamet etmeyi tercih etmektedir. ${ }^{24}$ Ürün çeşitliliğinin bol olması dolayısıyla bostancılık emek yoğun bir çalışma gerektirir. Her ürünün olgunlaşma süreci, hasat zamanı gibi özellikleri farklı olduğundan tarım faaliyetlerine ara verilen iki ay dışında bostancılar günlerinin büyük bir bölümünü bostanlarında geçirirler:

Sabahın altısında kalkıyoruz, yazın bazen gecenin birine ikisine kadar çalışıoruz ... Şuraya maydanoz atıcam ... Buraya karalahana ekicem, ... bir alta pırasanın olduğu yere pazı atıcam. Yaklaşık altı ay orada durur. Onun altında reyhan, yanında nane var, onun altına da dereotu atıcaz. Dereotu döngü ister. Semizotu döngü ister. Pazı her altı ayda bir değişmek ister ... Tarlayı yeniden sür, yeniden aç, yeniden tohum at. Topladın bitti değil. ${ }^{25}$

Bostancılık farklı ürünlerin sınırlı bir alanda ekim, dikim, bakım ve hasadına dair bilgi birikimi, tecrübe ve organizasyon becerisi gerektirir. Genellikle meslek olarak ailenin babasına atfedilen bu zanaat aslında bir nevi küçük aile işletmesi şeklinde sürdürülür ve çekirdek aile bireylerinin tümü, özellikle de bostancıların eşleri, tarımsal üretim faaliyetlerine düzenli olarak katılır. ${ }^{26} \mathrm{Bu}$ durum mesleki bilgi ve becerilerin kuşaktan kuşağa uygulamalı olarak aktarılmasını da sağlar.

Bostancılar hangi ürünün ne zaman ekileceğine dair hesaplamalarında Tanzimat döneminden 1926 yılına kadar resmi ve mali kayıtlar için kullanılmış olan Rumi takvimi esas alırlar. Hesaplamalarını yaparken kullandıkları ya da referans aldıkları herhangi bir yazılı kaynak bulunmamaktadır. Yedikule Bostancılar Derneği Başkanı Özkan Ökten, bu yöntemin önemini ve inceliklerinin nasıl aktarıldığını şöyle açıklar:

Öğrendiğimiz ... dedelerimizden, babalarımızdan gördüğümüz oydu. ... Bu miladi takvim zaten o zaman yoktu, dedelerimiz onunla çalışmış. Biz de bunu takip etmek zorundayız yani, bize gösterilen, bize öğretilen bu ... Rumi yıla göre hareket etmezsem yaptığım ekim boşa çıkar. Sen şimdi yaz geldi diye, bu güneşi gördün, bir tohum atarsın yere ama aslında patlamaz. Üç gün sonra büyük bir soğuk gelecek. Ama eski takvim sana söylüyor neyin ne olduğunu ... Kasım’ takip ediyorsun Rumi yıldan, kasım seksen der, doksan der, yüz der... Mesela dedem derdi ki: 'kasımın sekseninde bunu atacaksın, doksanında şunu.' Ürünlerin günleri var... Mesela pazıyı bundan on gün önce atarsın tohuma kaçar, on gün sonra atarsın tohuma kaçmaz. Pancarı, 15 Temmuz'a kadar atarsın döner, pancar yapar; 16'sında atarsın dönmez. Yaprak yapar, baş yapmaz alttan. Bir günle kaybedersin. ${ }^{27}$

Yedikule'de son yıllarda dünyada ve Türkiye'de kullanımı gittikçe artan hibrit tohum yerine bostancıların kendi ürettikleri ve "dede tohumu" adı verdikleri yerli tohumlar kullanılır. ${ }^{28}$ Her bostancının elinde yıl boyunca ektiği sebze ve yeşillik çeşitlerinin tohumları bulunur. Yaptığımız görüşmelerde bostancılar hibrit tohumun tek seferde daha çok ürün vermesine rağmen uzun vadede toprağın verimini düşürdüğünü ve kimyasal tarım ilaçlarının kullanımını arttırdığını, dede tohumlarından ise daha az verim alınmasına rağmen çok daha kaliteli ve lezzetli ürün elde ettiklerini belirttiler. Dede tohumları, tek-tip ve tek seferlik hibrit tohum kullanımının yaygınlaşmasıyla azalan yerel biyoçeşitliliğin korunması ve geliştirilmesi açısından da önem taşır. Bostancılarda tohum bankalarında olmayan ürün çeşitleri bulunmaktadır. Örneğin, Yedikule'nin ünlü yağlı marulu hala ve sadece bu bostanlarda yetiştirilir. ${ }^{29}$ Bostancılar için tohumları çok değerlidir. Zaten çoğu akraba ya da hısım olan bostancıların kendi aralarında tohum değiş tokuşu sık olurken, tohumlarını satmazlar ya da bostancı olmayanlara vermezler:

Bizans döneminden beri buralarda kalan tohumlardır [dede] tohumları ... Tohum bankasında böyle bir şey yok ... Biz tohumu zaten kimseye vermiyoruz, kimseden de tohum almiyoruz. Mesela tohumum bitmiş ... Diyorum ki dayıma, dayı ben maydanoz tohumu bu sene yeterli alamadım ... Dayım diyor ki bir kilo fazla var veririm sana. Ondaki bir kiloyu alıyorum. Gidiyorum amcama ... o diyor ki yarım kilo veririm sana ... Ya da diyelim ki benim kendi ürettiğim tohum ... beni cezbetmiyor. Geliyorum bu kardeşimizin tohumu benimkinden daha iyi dede tohumu bununkiyle değiştiriyorum. Diyorum sen bana yarım kilo maydanoz tohumu ver bu sene bundan tohum alacağım ... Yani yerli tohum ... sen gelsen bana beş milyar versen ben sana vermem. ${ }^{30}$

Bostancılık, tarımsal kimyasal ilaç ve gübrelerin sıklıkla kullanıldığı ve teknolojik gelişmelerle kolaylaşmış endüstriyel tarımdan çok farklıdır. Bostancılar neden geleneksel teknik ve yöntemleri tercih ettikleri sorulduğunda, yetiştirdikleri ürünlerin endüstriyel tarım ürünlerine göre çok daha doğal ve sağlıklı olduğunu vurgulamıştır:

Organik tarım fazla bir yerde kalmadı. Bizim yaptığımız organik tarım. Hiçbir ilaç kullanmadan, doğal gübreyle, doğal yetiştirmeyle devam ediyor... Endüstriyel tarım büyük arazi. Ilaçlı

${ }^{24}$ Özkan Ökten, 02.03.2018 tarihli görüşme

${ }^{25}$ Özkan Ökten, 02.03.2018 tarihli görüşme

${ }^{26}$ Bostancılar genellikle eşleriyle birlikte çalıştıklarını, çocuklarının da hafta sonlarında, okuldan veya işten döndüklerinde kendilerine yardım ettiğini belirtmiştir. Özellikle yaz ayları gibi aile emeğinin yeterli olmadığı dönemlerde ücretli işçi de çalıştırmaktadırlar.

27 Özkan Ökten, 27.04.2018 tarihli görüşme.

${ }^{28}$ Görüşmelerimizde sadece bir bostancı, bostanının IBB projesi kapsamında düzenlenecek alanda bulunmasından dolayı kısa dönemde yüksek verim almak için, hibrit tohuma geçtiğini belirtmiştir. Bostancı Sami Bey, 03.04.2018 tarihli görüşme.

${ }^{29}$ Özkan Ökten, 27.04.2018 tarihli görüşme.

${ }^{30}$ Özkan Ökten, 02.03.20I8 tarihli görüşme. 
olduğundan çabuk sirküle edilmeli. Ama bostanda ilaç kullanılmaz. Antalya'ya gittim gördüm. Adam sırtına makineyi almış ilaç basiyor, toz duman içerisi ... Ben büyük arazim olsa bile endüstriyel tarıma geçmezdim. Bostan çok emek istiyor. Ama buradaki maydanozun, nanenin kokusu hiçbir yerde yok. ${ }^{31}$

Hormon ilacı bilmem ben. Hiç kullanmadım ... Gübre olarak da hayvan gübresi kullandım. Her şey eski usul. Ürünlerimiz doğal. Bizim yediğimiz, çoluğumuzu çocuğumuzu buradan besledik... Diktiğin şey de öyle aynı, çocuk gibi büyütüyorsun onu. ${ }^{32}$

Endüstriyel çıkalı beri geleneksel tarım öldü sayılır. Beden gücümüzle çalışıorduk biz. Şimdi makine çıktı. Bizim gibi nerede yorgun olacaklar. Biz sabah beşte kalkardık, hemen havaya bakardık. Şimdi adam kaçta kalkarsa kalkıyor, çekip gidiyor ... Malı yetiştirmek için yeni bir şey çıkmış, atıyorsun malın hemen oluyor... Yemyeşil domatese atıyor akşamdan, sabah topluyor, domates pespembe ... Ürünün kalitesi gitti işte ... Ben hiç makine tohumu bilmiyorum. Maydanozu, dereotu, teresi olsun biz kendimiz çıkarırdık. Şimdi adam 'alo' diyor tohumu fabrikadan geliyor. Her şeyin sahtesi çıktı yani. ${ }^{33}$

Yedikule bostancıları modern tarım araç ve gereçlerinden ziyade kazma, çapa, kürek çekiç, tırmık gibi geleneksel aletlerle üretim yaparlar (Şekil I3). Yakın dönemde karasabanın yerini alan çapa makinası dışında tarım makinası kullanmazlar. Dede tohumlarını ve fideleri elle eker ve hasadı elle yaparlar. Tohumun filiz atıp kök salabilmesi için hava almasını engellemek amacıyla, takunya adını verdikleri ağır paletli tahtalarla yürüyerek ya da patpat denilen bir aletle vurarak toprağı sıkıştırırlar. Ekilen alan daha büyük olduğunda ise silindir taşı diye adlandırdıkları bir alet kullanırlar. Bu aleti bir metre çapında demir bir borunun içine beton döküp yanlarına birer demir çubuk geçirerek kendileri hazırlarlar (Şekil 14).

Sulama için bostanlarda bulunan taş kuyular kullanılır (Şekil 15). Yedikule'nin yüksek rakımı dolayısıyla oldukça derin olan bu kuyuların bakımını da bostancılar üstlenir (White, Shopov ve Ostovich, 2015, s. 32):

Benim kullandığım kuyunun 25 metre derinliği 6 metre genişliği var. Tarihi eser, ama kimse bilmiyor ne zaman açıldığını ... Hiç kapanmaz ... Ama yağmur çamur birikti mi temizliyorsun. Giriyorsun mesela kuyuya asansör yapıyorsun. Seni saliyorlar kuyunun dibine. Oradan kovaya çamur dolduruyorsun. Bir kişi yukarıdan çekiyor, boşaltıyorsun. ${ }^{34}$

Bostanlar günümüzde yaygın kullanılan yağmurlama ya da damla sulama yöntemleri yerine geleneksel tavalama yöntemi

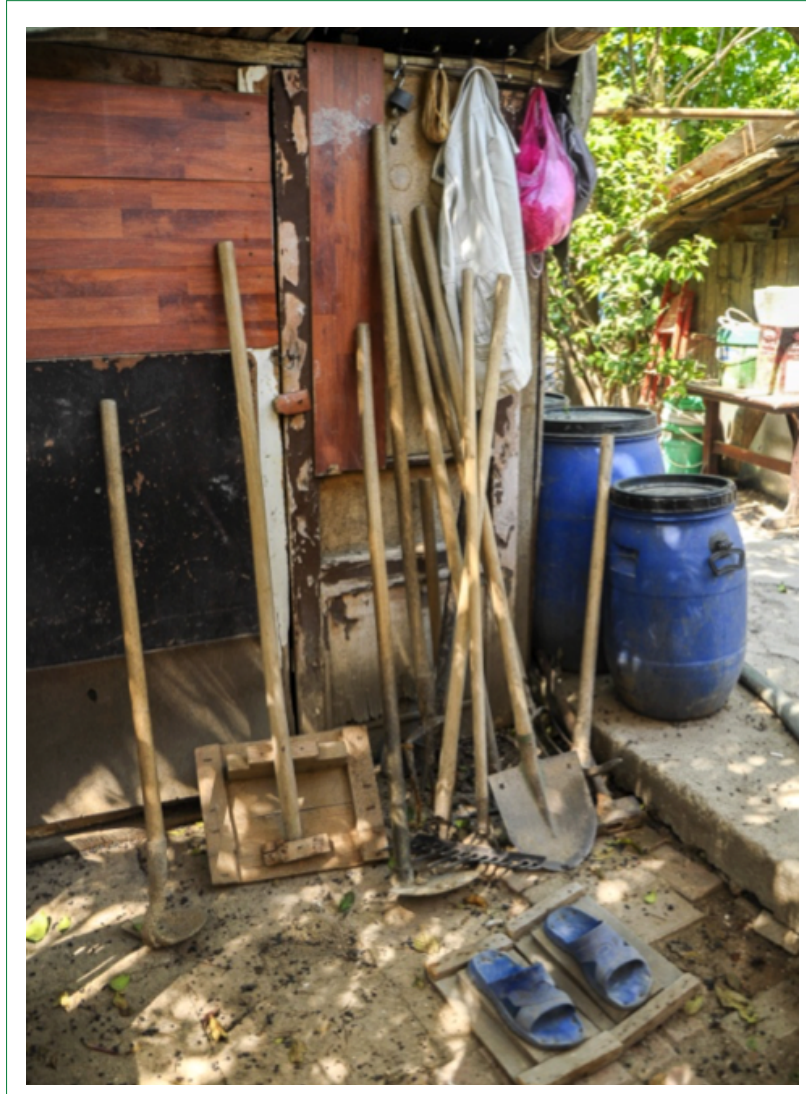

Şekil I3. Bostancıların ürünlerini ekip dikerken kullandıkları geleneksel aletler; kazma, çapa, kürek, çekiç, tırmık, paletli tahta vs.

(Yazara ait, 27.04.2018)

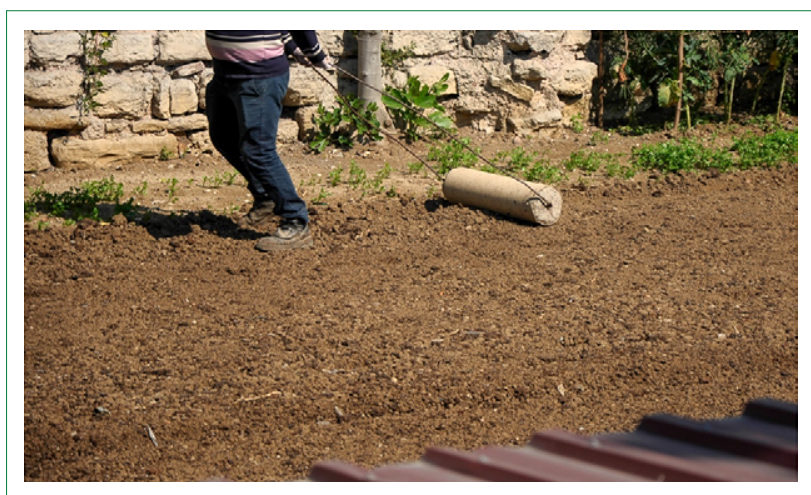

Şekil I4. Bostancıların toprağı sıkıştırmak için kendilerinin hazırlayıp kullandıkları geleneksel bir alet olan silindir taşı.

(Yazara ait, 27.04.18)

ile sulanır. Erken yirminci yüzyıla ait fotoğraflarda da görülen bu yönteme göre toprak bir satranç tahtası gibi l'e I.5 metre ebatlarında ve kenarları $10 \mathrm{~cm}$. yüksekliğinde maşula adı verilen alanlara bölünür (White, Shopov ve Ostovich, 2015, s. 33)

\footnotetext{
${ }^{31}$ Bostancı Kemal Bey, 13.05.2018 tarihli görüşme.

${ }^{32}$ Bostancı Mehmet Bey, 04.05.2018 tarihli görüşme.

${ }^{33}$ Yedikule'de 42 sene bostancilık yaptıktan sonra bostanına moloz dökülen Cemal Bey, 20.05.2018 tarihli görüşme.

${ }^{34}$ Bostancı Sami Bey, 03.04.20I8 tarihli görüşme.
} 
(Şekil 16). Su maşulaların arasında açılmış su yollarına salınır ve bostancı toprağı şekillendirerek suyu istediği bölgeye yönlendirir. Hem verim hem de su tasarrufu sağlayan bu yöntemle su aynı alandaki bitkiler arasında eşit dağılır, farklı ürünler yan yana büyüyebilir (White, Shopov ve Ostovich, 20I5, s. 33):

Boylamasına su yolları açarsın, iki kişi sulamaya başlarsın. Birimiz 'suyu kes' dediği zaman diğeri keser... Maşulaları patlatmazsın o zaman. Patlatmazsın derken, su fazla kaybolmasın, toprağı süzgeç yapmasın diye ... Bizim sistem hem sağılılı hem de toprağı verimli kılıyor ... Elle yaparsan hem toprak suya kanar, hem verimi daha güzel alırsın. Benim elle suladığım yerde tüm mahsül çıkar, [ hortum ya da fiskiye] ile sulamada ise bir orada çıkar bir burada. Verim olmaz. Çünkü ... toprak yeterince su almıyor. ${ }^{35}$

\section{Sonuç ve Değerlendirme}

Tarihi kara surları, askeri mimari açıdan Avrupa ve Yakın Doğu'da bir referans noktası olmuş olması nedeniyle sözleşmenin ikinci kriterine, Bizans ve Osmanlı uygarlıklarına eşsiz bir tanıklık teşkil etmesi dolayısıyla da üçüncü kriterine göre istisnai evrensel değer olarak tanımlanmış ve koruma altına alınmıştır (UNESCO, 20I8a). Ancak kara surlarının bostanlarla bir bütün olarak korunması gerektiğini savunan Aksoy'un (2016) da belirttiği gibi: "Bostansız surlar olsa olsa kimliği eksiltilmiş, ışıklandırılmış görüntüye indirgenirler; yaşayan değil cansız surete dönüşürler.”

Dünya Mirası Sözleşmesi, kültürel peyzaj kategorisinin yürürlüğe girmesinden önce sadece arkeolojik ve mimari özellikleri nedeniyle listelenmiş unsurların, barındırdıkları somut olmayan öğeler de dikkate alınarak tekrar aday gösterilmesine olanak sunmaktadır. Bir önceki bölümde detaylandırdığımız Yedikule bostancılığının kendine has özellikleri ve incelikleri, geleneksel arazi kullanımının günümüzde yaşayan özgün ve nadir bir örneği olduğunu açıkça göstermektedir. Ürün çeşitliliğinin yüksek olması, doğal tarım yöntemleri ve dede tohumuyla üretim yapılması bostancılı̆ı̆n yerel (ve de küresel) biyoçeşitliliğin sürdürülmesi açısından önemini ortaya koyar. Yüzyıllar boyunca gelişen ve hala geleneksel işlevini devam ettiren bu kültür ve bilgi birikimi, dünya genelinde gittikçe popülerleşen kentsel organik çiftçilik için de bir model niteliğindedir (Durusoy ve Cihanger, 2016, s. 127). Bu bağlamda, Yedikule bostancılık geleneği, Dünya Mirası Sözleşmesi'nin kültürel peyzaj anlayışıyla bire bir örtüşmektedir:

Kurulu oldukları doğal çevrenin özellikleri ve kısıtılıkları düşünüldüğünde, kültürel peyzaj alanları sıklıkla sürdürülebilir arazi kullanımının özgün tekniklerini yansıtmaktadır ... Kültürel peyzaj alanlarının korunması modern sürdürülebilir arazi kullanımı tekniklerine katkıda bulunabileceği gibi, peyzajın do-

\footnotetext{
${ }^{35}$ Bostancı Kemal Bey, 13.05.2018 tarihli görüşme.
}

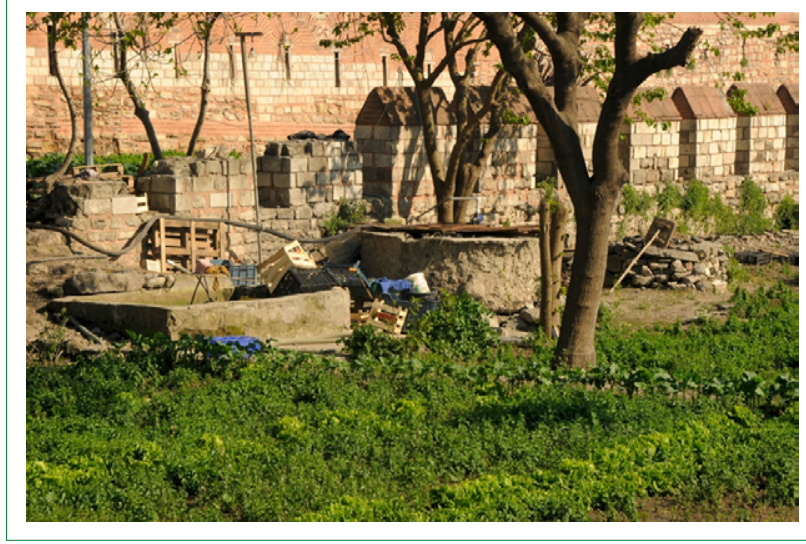

Şekil I5. Bostanların sulamasında kullanılan Osmanlı döneminden kalma tarihi kuyu.

(Yazara ait, 28.04.2017)
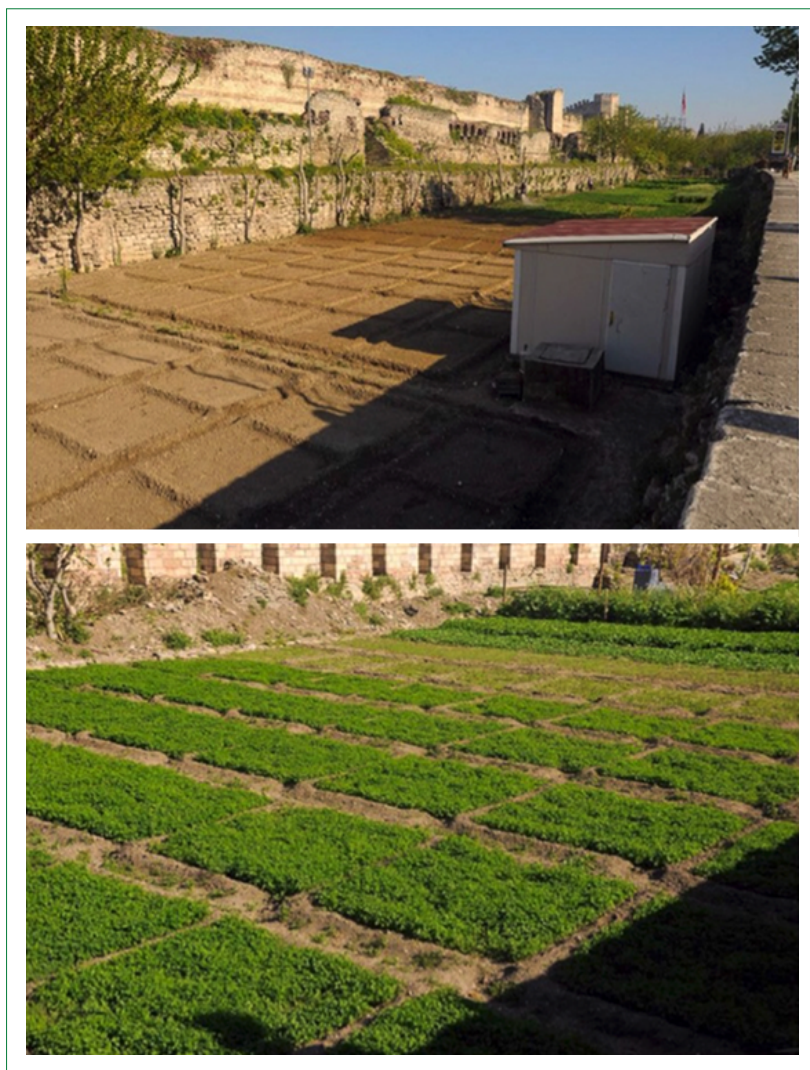

Şekil 16. Bostancılar tarafından tavalama yöntemiyle sulayabilmek için maşulalara ayrıımış alan.

(Yazara ait, 28.04.2017)

ğal değerlerinin sürdürülmesi veya geliştirilebilmesini de sağla yabilir. Geleneksel arazi kullanımı formlarının varlığını devam ettirmesi dünyanın birçok bölgesinde biyolojik çeşitliliği destekler. Kültürel peyzaj alanlarının korunması bu yüzden biyolojik çeşitliliğin sürdürülmesine yardımcı olur. (UNESCO, 20l8b) 
Kara surları ve bostancılığı geleneksel arazi kullanımı ve yaşam biçimleriyle ilişkilendirilen ama toplumdaki aktif sosyal rolü devam eden gelişimini sürdüren organik peyzaj kategorisi altında yeniden listeleyerek birlikte koruma altına almak mümkündür. ${ }^{36}$ Yedikule bostancılığı, kültürel peyzajı da kapsayan yeni kriterlere göre "yaşayan ... bir kültür geleneğinin ... ender rastlanan bir temsilcisi” olması dolayısıyla sözleşmenin üçüncü kriterine göre üstün evrensel değer taşır. Ayrıca, "çevre ve insan etkileşiminin" ve "geleneksel ... arazi kullanımının" bir örneği olarak beşinci kriter kapsamına ve yaşayan bir gelenek olarak altıncı kriter kapsamına girer. Kültürel peyzaj olarak listelenecek unsurların aynı zamanda, diğer kategorilerde olduğu gibi, bütünlük ve otantiklik özelliklerini taşıması gerekir. Kültürel peyzaj bağlamında otantiklik testi "bir alanın olduğunu iddia ettiği şeylerin gerçek ve özgün bir temsilcisi” olup olmadığı üzerinden uygulanır (von Droste, Rössler ve Titchen, 1999, akt. Fowler, 2003, s. 20). Gelişimini sürdüren organik peyzaj alanının bütünlügü ise "geleneksel işlevlerinin devamlılığ” üzerinden değerlendirilir (von Droste, Rössler ve Titchen 1999, akt. Fowler, 2003, s. 20). Yedikule bostancılığı geleneksel kentsel tarımın yaşayan, özgün ve bozulmamış bir temsilcisi olması dolayısıyla hem otantiklik hem de bütünlük koşullarını karşılar.

Bostancılar, kara surları ve bostanların bütüncül bir anlayışla korunması gerektiği düşüncesini paylaşmaktadır. Bölgedeki yenileme çalışmalarının sadece bostanlara değil surlara da zarar verdiğini belirten bostancılar, bu duruma örnek olarak 2006 yılında yol büyütme çalışmaları esnasında Yedikule kapısının yanındaki surların kepçe darbesiyle yıkılmasını ya da surun iç tarafındaki bostan alanlarına moloz dökülmesi sırasında surların temelinin zarar görmesini göstermişlerdir. ${ }^{37}$ Surların olduğu gibi korunması gerektiğinin bilincinde olduklarını dile getiren bostancılar, surlara zarar verecek faaliyetlerden kaçındıklarını ve hatta surların uyumak, uyuşturucu kullanmak, tuvalet ihtiyacını gidermek ya da içki içmek gibi amaçlarla kullanılmasının sık sık önüne geçtiklerini belirtmişlerdir. Bostancılar, IBB ile sürekli iletişim halinde oldukları takdirde kara surları ve bostanların daha sürdürülebilir ve sistematik bir şekilde korunabileceğinin altını çizmektedir. Özkan Ökten, bostancıların bu konuya bakışını şöyle özetlemektedir:

Surlarla biz bir bütünüz. Yani tarihlerden bu yana, burada bu böyleymiş. Biz de bu kültürü, bu varlı̆ı burada yaşatmak istiyoruz ... Surlar yapılsın, tadilata girsin. Biz de buna destek verelim, el verelim ... bostancılı̆̆ burada sürdürelim ... Yirmi tane bank atıp buralara tinercileri, balicileri toplamaktansa, biz bu kültürel mirası burada yaşatalım ... Bizim buradaki bir amacımız da surları korumak ... Ama surun dibine gider bir incir fidesi dikerseniz sura zarar vermiş olursunuz. Bunu bilerek yapmazsınız... Incir büyümüş, büyümüş sura yaslanmış. Bunu bilememişsiniz ... Belediyemizin gelip bize en azından akıl vermesi lazım ... Yarın ben ölebilirim, benim çocuğum bu işi yapmayabilir ... Ama önemli olan bu işi bitirmemek. Belediyemizin de burada bize katkı vermesi lazım. Demesi lazım ki, 'siz bu bostancilığ yapıyorsunuz, biz size bir okul açalım' ... veya 'sizin yanınızda yetişecek insanlar bulalım. ${ }^{38}$

Kara surları ve Yedikule bostancılık geleneğinin birlikte Dünya Mirası olarak tanınması, bostanları yeşil alan olarak gören anlayışın ortadan kalkmasına yardımcı olacağı gibi, bostancılık geleneğinin parçası olduğu kültürel peyzajının bir bütün olarak sürdürülebilirliğinin sağlanması bakımından da önemlidir. Aslında, hükümetlerarası bir kurum olan ve meşruiyetini üye devletlerden alan UNESCO'nun sözleşmelerine taraf olan devletler üzerinde direkt olarak bir yaptırım gücü bulunmamaktadır. Uluslararası hukuk ulus-devletler tarafından düzenlendiğinden, UNESCO sözleşmelerinin yürütülmesi ve uygulanmasında devlet kurumları belirleyicidir (Blake, 2009, s. 47). Bu durum, Dünya Mirası Sözleşmesi için de geçerlidir: hangi kültürel öğelerin dünya mirası listelerine aday gösterileceği, bu öğelerin nasıl tanımlanacağı ve korunacağı ulusal düzeyde ve devlet yetkilileri tarafından belirlenir. Ancak Dünya Mirası Sözleşmesinin sadece kâğıt üzerinde kaldığı düşünülmemelidir. Ashworth ve Bart'a göre, sözleşme bu yönüyle sınırlı olsa da yine de etkilidir, çünkü dünya kamuoyunu etkileyen, harekete geçiren ve dolayısıyla ulusal hükümetleri ikna edebilecek ya da onlara dolaylı yollardan baskı yapabilecek bir konumda$\operatorname{dir}$ (Ashworth ve Bart, 2006, s. I55). ${ }^{39}$

Bu bağlamda, Yedikule bostancılığının sözleşme nezdinde kültürel miras olarak tanınması ve tanımlanması bu geleneğe bir meşruiyet kazandırarak surlarla birlikte korunması konusunda ulusal ve uluslararası düzeyde kamuoyu oluşumuna katkı sağlayacaktır. Ayrıca, bu geleneğin sözleşme kapsamına dahil edilmesi bostancıların Yedikule'deki bostan alanlarında üretim yapmalarına devam edebilmelerine ve bu alanın yönetim ve

361997 yılında gelişimini sürdüren organik peyzaj olarak Dünya Mirası Listesi'ne alınan Portovenere, Cinque Terre ve Palmaria, Tino ve Tinetto Adaları, bu değişiklik için bir örnek oluşturabilir. Adaylık dosyasına göre, bölge topluluklarının sosyo-ekonomik hayatında önemli bir rol oynayan teraslı tarım geleneğinin ve bu gelenekle bütünleşen küçük ölçekli ve kompakt yerleşim biçimlerinin binlerce yıldır sürdürüldüğü bu peyzaj alanı, yöreye has geleneksel yaşam tarzının yaşayan bir örneği olarak istisnai evrensel değere sahiptir (UNESCO, 2018c).

${ }^{37}$ Kara Surların bu çalışmalar esnasında gördüğü zarar İstanbul Kara Surları Dünya Miras Alanı Koruma Sorunları İzleme Raporu - Tarihi Yedikule Bostanları Üzerine Özel Bir İnceleme isimli raporda da ayrıntılı olarak tartışılmış ve fotoğraflarla belgelenmiştir. Bkz: Çorakbaş, Aksoy ve Ricci, 2014, s. I0-15.

38 Özkan Ökten, 27.04.2018 tarihli görüşme.

${ }^{39}$ Bu durum, Tarihi Yarımada özelinde de yaşanmıştır. 2005 yılında onaylanan Haliç metro geçiş köprüsü projesinin Tarihi Yarımada'nın üstün evrensel değerine geri dönülmez bir biçimde zarar vereceğine yönelik eleştiriler 2010 yılındaki 34. Dünya Mirası Komite Toplantısına taşınmıştır. Bu toplantıda bu eleştirinin haklı bulunmasının ardından Tarihi Yarımada'nın Tehlike Altındaki Dünya Mirası listesine alınması ya da listeden tamamen çıkarılması gündeme gelmiştir. UNESCO'nun talebi üzerine IBBB bağımsız yabancı bilim adamlarından oluşan iki ekip kurmuştur. Bu uzmanların talepleri doğrultusunda köprünün çevresiyle bütünlük arz etmesi için rengi değiştirilmiş, 82 metre olarak planlanan kuleleri 65 metreye ve çelik kablo bağlantıları 47 metreye indirilmiştir. Bu konuda ayrıntılı bir tartışma için, bkz. Siviero et al., 20। 7; Vardar 20।4. UNESCO'nun benzer müdahalelerini tartışan bir literatür için, bkz. Logan 2014; Manhart 2016. 
karar alma süreçlerine katılımlarına olanak tanıyacaktır. 2013 yılında moloz dökülen alan hala bostana dönüştürülebilir ve orada üretime devam etmek isteyen eski sahiplerine geri verilebilir. Halihazırda dernek çatısı altında tüzel kişiliğe sahip Yedikule bostancılarının sözleşmenin karar alma mekanizmalarına ve bu alanın Dünya Mirası olarak yönetimi süreçlerine kolektif katılımını sağlamak da mümkündür.

Son olarak, Yedikule bostancılığının koruma altına alınması, İstanbul'un yok olmaya yüz tutmuş bostancılık geleneğini sadece Yedikule özelinde değil, İstanbul genelinde resmî kurumlarca desteklenerek yaşatılmasına yönelik politikalar ve projeler geliştirmeye imkan sağlayacaktır. Bu durum, bostancılığın bir zanaat olarak tanınıp UNESCO İnsanlığın Somut Olmayan Kültürel Mirasının Temsili Listesi'ne kaydedilmesine de önayak olabilir. Nitekim, Ebru, Çini ustalığı ve Meddahlık gibi yok olmaya yüz tutmuş geleneksel zanaatlar bu listeye dahil edilerek koruma altına alınmıştır. Bostancılık da bu listeye dahil olmak için gereken niteliklere sahiptir.

\section{Teşekkür}

Araştırmaya katılan Yedikule bostancılarına ve bu araştırmanın veri toplama aşamasına katkıda bulunan Sinem Çelik, Gönül Karabolu ve Halil İbrahim Kılıç’a teşekkür ederiz.

\section{KAYNAKLAR}

Ahmad, Y. (2006). The Scope and Definitions of Heritage: From Tangible to Intangible. International Journal of Heritage Studies, 12(3), 292-300.

Akdal, A. N. (2017). Market Gardens and Gardeners of Ottoman İstanbul. İstanbul: Libra.

Akdaş, U. (2010). İstanbul'un 100 Bahçesi. İstanbul: İBB (Kültür A.Ş.) Yayinları.

Anico, M., Elsa, P. (Ed.) (2009). Heritage and Identity - Engagement and Demission in the Contemporary World. New York: Routledge.

Ashworth, G. J., Bart J. M. van der Aa (2006), Strategy and Policy for the World Heritage Convention: goals, practices and future solutions, Leask, A., Fyall, A. (Ed), Managing World Heritage Sites içinde (s. 147- 158). Oxford: Elsevier.

Aykan, B. (2010). National politics and cultural sustainability: the case of the Mevlevi Sema ceremony of Turkey. Amoeda, R., Lira, S. \& Pinheiro C. (Ed.), Proceedings of the $2^{\text {nd }}$ International Conference on Heritage and Sustainable Development içinde (s. 725-733). Greenlines Institue.

Aykan, B. (2012). UNESCO ve Kültürel Mirasın Milliyeti P. M. Yelsalı Parmaksız (Ed.), Neye Yarar Hatıralar? Bellek ve Siyaset Çalışmaları içinde (s. 303-337). Ankara: Phoenix.

Baillie, B., Chippindale, C. (2007). Tangible-Intangible Cultural Heritage: A Sustainable Dichotomy? The $7^{\text {th }}$ Annual Cambridge Heritage Seminar. 13 May 2006. McDonald Institute for Archaeological Research. University of Cambridge: UK.

Barthel-Bouchier, D. (2013). Cultural Heritage and the Challenge of Sustainability. London: Left Coast Press.

Basat, E. M. (2013). Somut ve Somut Olmayan Kültürel Mirası Birlikte Koruyabilmek. Milli Folklor, 25(100), 61-71.

Beazley, O., Deacon, H. (2007). The Safeguarding of Intangible Heritage Values under the World Heritage Convention: Auschwitz, Hiroshima and Robben Island. Janet Blake (Ed.), Safeguarding Intangible Cultural Heritage: Challenges and Approaches içinde (s. 93-107). Builth Wells: Institute of Art and Law.

Blake, J. (2000). On Defining the Cultural Heritage. International and Comparative Law Quarterly, 49(1), 61-85.

Blake, J. (2009). UNESCO's 2003 Convention on Intangible Cultural Heritage: the implications of community involvement in safeguarding. Smith, L., Akagawa, N. (Ed.), Intangible Heritage içinde (s. 45-73). New York: Routledge.

Byrne, D. (2009). A Critique of Unfeeling Heritage. Smith, L., Akagawa, N. (Ed.), Intangible Heritage içinde (s. 229-52). New York: Routledge.

Çorakbaş, F. K., Aksoy, A. \& Ricci, A. (2014). İstanbul Kara Surları Dünya Miras Alanı Koruma Sorunları İzleme Raporu: Tarihi Yedikule Bostanları Üzerine Özel Bir İnceleme. M. Konuk (Çev.). İstanbul.

Di Giovine, M. A. (2014). The Everyday as Extraordinary: Revitalization, Religion, and the Elevation of Cucina Casareccia to Heritage Cuisine in Pietrelcina, Italy. Brulotte R. L., Di Giovine, M. A. (Ed.), Edible Identities: Food as Cultural Heritage içinde (s. 77-91). Surrey: Ashgate.

Durusoy, E., Cihanger, D. (2016). Historic Landscape vs. Urban Commodity?: The Case of Yedikule Urban Gardens, İstanbul. Megaron Dergisi, 11(1), 125-136.

Fowler, P. J. (2003). World Heritage Papers 6: World Heritage Cultural Landscapes 1992-2002. UNESCO World Heritage Centre, vol: 6.

Günçıkan, B. (1990, 15 Aralık). Semt bostanı betona yenildi. Cumhuriyet Gazetesi, s. 15.

Graham, B., Howard P. (2008). Heritage and Identity. Graham B., Howard P. (Ed.), The Ashgate Research Companion to Heritage and Identity içinde (s. 1-15). Hampshire: Ashgate, 
Hafstein, Tr. V. (2009). Intangible Heritage as a List: from masterpieces to Representation, L. Smith., N. Akagawa (Ed.), Intangible Heritage içinde (s. 93-111). Abingdon: Routledge.

Hall, S. (2005). Whose Heritage? Un-settling 'The Heritage', Re-imagining the Post-nation. Littler, J., Naidoo, R. (Ed.), The Politics of Heritage The Legacies of 'Race' içinde (s. 21-31). New York: Routledge.

Hodder, I. (2010). Cultural Heritage Rights: From Ownership and Descent to Justice and Well-being. Anthropological Quarterly, 83(4), 861-82.

Jalais, A. (2007). The Sundarbans: Whose World Heritage Site?. Conservation and Society, 5(3), 335-342.

Kaldjian, P. J. (2004). Istanbul's Bostans: A Millenium of Market Gardens. Geographical Review, 94(3), 284-304.

Laurajane, S. (2006). The Uses of Heritage. New York: Routledge.

Lixinski, L. (2011). Selecting Heritage: The Interplay of Art, Politics and Identity. European Journal of International Law, 22(1), 81-100.

Lixinski, L. (2013). Intangible Cultural Heritage in International Law. Oxford: Oxford University Press.

Logan, W. (2010). Protecting the Tay Nguyen Gongs: Conflicting Rights in Vietnam's Central Plateau. Langfield, M., Logan, W. \& Crait, M. N. (Ed.), Cultural Diversity, Heritage and Human Rights içinde (s. 189207). New York: Routledge.

Logan, W., Langfield, M. \& Craith M. N. (2010). Intersecting Concepts and Practices. Langfield, M., Logan, W. \& Craith M. N. (Ed.), Cultural Diversity, Heritage and Human Rights içinde (s. 3-20). New York: Routledge.

Logan, W. (2014). Heritage Rights-Avoidance and Reinforcement. Heritage \& Society, 7(2), 156-169.

Manhart, C. (2016). The Intentional Destruction of Heritage: Bamiyan and Timbuktu. Logan, W. Nic Craith, M., Kockel, U. (Ed.) A Companion to Heritage Studies içinde (s.280-294). Sussex: Wiley Blackwell.

Meskell, L. (2010). Human Rights and Heritage Ethics. Anthropological Quarterly, 83(4), 839-860.

Miura, K. (2005). Conservation of a 'Living Heritage Site' A Contradiction in Terms?: A case study of Angkor World Heritage Site". Conservation and Management of Archaeological Sites 7, 1, 3-18.

Ricci, A. (2008). İstanbul'da Manevi Kültürel Miras: Kara Surlarının Bizans Bahçeleri. (Uluslararası Tarihi Yarımada Sempozyumu Tebliğler Kitabı). İstanbul: Eminönü Belediyesi, s. 66-67.

Rössler M. (2006). World Heritage cultural landscapes: A UNESCO flagship programme 1992 - 2006. Landscape Research, 31(4), 333-353.

Sammells, C. A. (2014). Haute Traditional Cuisines: How UNESCO's List of Intangible Heritage Links the Cosmopolitan to the Local. Brulotte, R. L., Di Giovine, M. A. (Ed.), Edible Identities: Food as Cultural Heritage içinde (s. 141-158). Surrey: Ashgate.

Sezer, Y. (2004). Kamu Mallarında Ecrimisil. Danıştay Dergisi, 108, 5-22.

Shadreck, C., Manyanga, M., Ndoro, W. \& Pwiti G. (2010). Unfulfilled promises? Heritage Management and Community Participation at some of Africa's Cultural Heritage Sites. International Journal of Heritage Studies, $16(1-2)$, 30-44.

Shopov A., Han, A. (2013). Osmanlı Istanbul'unda Kent Içi Tarımsal Toprak Kullanımı ve Dönüşümleri: Yedikule Bostanları. Toplumsal Tarih, 34-38.

Silverman, H. (2011). Contested Cultural Heritage: A Selective Historiography. Helaine Silverman (Ed.), Contested Cultural Heritage içinde (s. 1-50). New York: Springer.

Siviero, E., Culatti, M., Martini, V. \& Stocco A. (2018). Haliç Metro Crossing Bridge. A Bridge in the Historical Heart of İstanbul. Koui, M., Zezza, F,, Kouis, D. (Ed.), $10^{\text {th }}$ International Symposium on the Conservation of Monuments in the Mediterranean Basin içinde (s. 677-690). New York: Springer.

Suman, D. (2008). Tamales \& Bollos- Patrimonio De La Humanidad/ World
Heritage: Challenges Faced by Restoration Efforts in Panama City's San Felipe Historic District. Tennessee Journal of Law and Policy, 4(2), $403-$ 465.

Swanson, K. K., Timothy, D. J. (2012). Souvenirs: Icons of Meaning, Commercialization and Commoditization. Tourism Management, 33(3), 489-499.

Taylor, K., Altenburg, K. (2006). Cultural Landscapes in Asia-Pacific: Potential for Filling World Heritage Gaps. International Journal of Heritage Studies, 12(3), 267-282.

White, C., Shopov, A., \& Ostovich, M. (2015). An Archaeology of Sustenance: The Endangered Market Gardens of Istanbul. Cherry J., Rojas F. (Ed.), Archeology for the People: Joukowsky Institute Perspectives, Joukowsky içinde (s. 29-38). Institute Publication, Oxford, UK: Oxbow Books, 7.

\section{INTERNET KAYNAKLARI}

Aksoy, A. (2016). Surları Bostanlarla Birlikte Yaşatmak. https://xxi.com.tr/i/ surlari-bostanlarla-birlikte-yasatmak [Erişim tarihi 24 Temmuz 2018].

Emen, İ., İnce, E. (2013). Bostandan 3 plan çıktı. http://www.radikal.com. tr/turkiye/bostandan-3-plan-cikti-1146869/ [Erişim tarihi 24 Temmuz 2018].

Fatih Belediyesi (2013). 2013 Yll Faaliyet Raporu. http://www.fatih.bel.tr/ icerik/8901/2013-yili-faaliyet-raporu/ [Erişim tarihi 25 Temmuz 2018].

Hazine Taşınmazlarının İdaresi Hakkında Yönetmelik (2007.19.06). Resmi Gazete. 26557. http://www.resmigazete.gov.tr/eskiler/2007/06/20070619-3.htm [Erişim Tarihi 3 Mart 2019].

İBB (2018). Yedikule Bostanları Tarım Konseptiyle Kentsel Tasarım Parkı Olarak Yaşatılacak. https://www.ibb.istanbul/News/Detail/34513 [Erişim tarihi 25 Temmuz 2018].

İnce, E. (2013). Bostanda Arkeolojik Tahribat Uyarısı. http://www.radikal. com.tr/turkiye/bostanda-arkeolojik-tahribat-uyarisi-1142401/ [Erişim tarihi 27 Temmuz 2018].

İstanbul Tarihi Yarımada Yönetim Planı (2011). http://www.alanbaskanligi. gov.tr/files/Yönetim \%20Planı_24şubat2012_k.pdf [Erişim tarihi 25 Temmuz 2018].

Kılınç, B. (2017). Aslıhan Demirtaş: İstanbul'un 1600 yıllık biricik kentsel tarım geleneği var-Yedikule Bostanları. http://www.sivilsayfalar. org/2017/05/31/aslihan-demirtas-istanbulun-1600-yillik-biricikkentsel-tarim-gelenegi-var-yedikule-bostanlari/ [Erişim tarihi 24 Temmuz 2018].

Sherkin, S. (2001). A Historical Study on the Preparation of the 1989 Recommendation on the Safeguarding of Traditional Culture and Folklore. https://folklife.si.edu/resources/unesco/sherkin.htm [Erişim tarihi 28 Mart 2019].

TYBKG (2017). Tarihi Yedikule Bostanları Koruma Girişimi. Dayanışma Mimarlığı. http://dayanismamimarligi.org/dosyalar.php [Erişim tarihi 25 Temmuz 2018].

UNESCO (1988). Operational Guidelines for the Implementation of the World Heritage Convention. https://whc.unesco.org/archive/opguide88.pdf [Erişim tarihi 25 Temmuz 2018].

UNESCO (2003). Somut Olmayan Kültürel Mirasın Korunması Sözleşmesi, M. Ö. Oğuz, P. Tacar \& Y. Özay (Çev.), https://ich.unesco.org/doc/ src/00009-TR-PDF.pdf [Erişim tarihi 28 Şubat 2019].

UNESCO (2008). Dünya Mirası Konvansiyonunun Uygulanmasına Yönelik İşlevsel İlkeler. http://www.alanbaskanligi.gov.tr/files/Uygulama\%20 Rehberi.pdf [Erişim tarihi 25 Temmuz 2018].

UNESCO (2018a). Historic Areas of İstanbul. https://whc.unesco.org/en/ list/356 [Erişim tarihi 25 Temmuz 2018].

UNESCO (2018b). Cultural Landscapes. https://whc.unesco.org/en/cultu- 
rallandscape/\#1 [Erişim tarihi 25 Temmuz 2018].

UNESCO (2018c). Portovenere, Cinque Terre and the Islands (Palmaria, Tino and Tinetto). https://whc.unesco.org/en/list/826 [Erişim tarihi 27 Temmuz 2018].

UNESCO (2019a). Coffee Cultural Landscape of Colombia. https://whc. unesco.org/en/list/1121 [Erişim tarihi 25 Haziran 2019].

UNESCO (2019b). Rice Terraces of the Philippine Cordilleras. https://whc. unesco.org/en/list/722 [Erişim tarihi 25 Haziran 2019].

Vardar, N. (2014). Tüm İtirazların Ardından Haliç Köprüsü. https://bianet. org/bianet/toplum/153027-tum-itirazlarin-ardindan-halic-koprusu [Erişim tarihi 25 Haziran 2019]. 